\title{
Hyvinvointivaltiokansalaisuusdiskurssit neljän suurimman puolueen eduskuntavaaliohjelmissa 1991-2019
}

ABSTRAKTI Tutkimuksen tavoitteena on tehdä näkyväksi millaisia ideologisia valintoja Suomen neljä suurinta puoluetta ovat tehneet eduskuntavaaliohjelmissaan suhteessa hyvinvointivaltiokansalaisuusdiskursseihin 1991 vuodesta alkaen. Tarkastelemme erityisesti vaaliohjelmissa tuotettuja kansalaisen poliittisia ja sosiaalisia oikeuksia ja velvollisuuksia sekä kansalaisen ja valtion välistä oikeudellinen sidettä ja sen legitimointia. Tarkastelemme puolueiden hyvinvointivaltiokansalaisuusdiskursseja pohjoismaisesta hyvinvointivaltiomallista käytävän kamppailun viitekehyksessä. Kansalaisuustulkinnat ohjaavat yhteiskuntapolitiikkaa ja esimerkiksi määritelmät kansalaisten tarpeista vaikuttavat palvelurakenteeseen. Tutkimuksen aineisto koostuu Kansallinen Kokoomus r.p.:n, Perussuomalaiset r.p.:n, Suomen Keskusta r.p.:n ja Suomen Sosialidemokraattinen Puolue r.p.:n eduskuntavaaliohjelmista vuosilta 1991-2019. Perussuomalaiset r.p.:n osalta aineisto kattaa vaalivuodet 1999-2019. Tutkimuksen menetelmällinen lähestymistapa on kriittinen diskurssianalyysi ja sen avulla pyritään erityisesti löytämään argumentaatiota ja keinoja, joilla vaaliohjelmissa perustellaan kansalaisuustulkintoja. Kansalaisen poliittisiin ja sosiaalisiin oikeuksiin ja velvollisuuksiin liittyen tunnistimme kaksi diskurssia: palveluiden kohteena olevan kansalaisen ja omatoimisen kansalaisen diskurssit. Kansalaisen ja valtion oikeudelliseen siteeseen ja legitimiteettiin liittyen tunnistimme kansanvallan diskurssin. Puolueiden diskurssien välillä ei ollut löydettävissä perustavanlaatuisia näkemyseroja, vaan erot liittyivät enemmänkin painotuksiin. 


\section{JOHDANTO}

Kansalaisen käsitettä määrittää ennen muuta yksilön ja julkisen vallan suhde, kuten kysymys kansalaisen asemasta ja vapaudesta (Selkälä 2013, 41). Kansalaisuustulkinnat heijastelevat yhteiskuntapolitiikan tekemistä ja sisältöä, ja hyvinvointivaltion järjestelmät ja instituutiot heijastavat siten vallitsevaa tapaa tulkita kansalaisuutta (Häikiö ym. 2011; Kokkonen 2004) sekä toimivat toisaalta myös vakuuttavina perusteluina valituille linjauksille. Yhteiskunnan taloudellinen, sosiaalinen ja poliittinen tilanne vaikuttaa niin ikään kansalaisen oikeuksien ja velvollisuuksien tulkintaan (Lindström 2010). Tässä tutkimuksessa lähestymme kansalaisuutta ensisijaisesti diskursiivisesti, jolloin kansalaisuus määrittyy siten, miten siitä puhutaan: kansalaisuuden kaltainen makrokäsite voidaan nähdä tietynlaisena järjestyskäsitteenä (Helne ym. 2004, 16). Kieli on keino saada kansalaisuus tuntumaan hallittavalta: kieli sisältää mahdollisuuksia nimeämisen ja kategorisoinnin avulla tapahtuvaan hallintaan (ks. Helne 2004, 26).

On tärkeää analysoida miten kansalaisia, esimerkiksi heidän tarpeitaan ja kykyjään, määritellään politiikan kentillä sekä kiinnittää huomiota näiden tulkintojen potentiaalisiin seurauksiin eri kansalaisryhmien kannalta. Eduskuntavaaliohjelmien kansalaisuustulkinnat voidaan nähdä poliittisiin tarkoituksiin tuotettuina ideaaleina, joihin sisältyy (usein) normatiivisia odotuksia: tulkinnat eivät siten kuvaa vain sitä millaisia kansalaiset "ovat", vaan myös millaisia heidän tulisi olla. Puolueet poliittisina toimijoina määrittelevät kansalaisuutta tavoilla, jotka sopivat niiden ideologisiin näkemyksiin.

Tässä tutkimuksessa olemme kiinnostuneita viimeisimmissä kolmissa eduskuntavaaleissa (2011, 2015 ja 2019) neljän suurimman joukkoon sijoittuneiden puolueiden eduskuntavaaliohjelmien hyvinvointivaltiokansalaisuuskäsityksistä. Tarkasteltavana ovat (aakkosjärjestyksessä) Kansallinen Kokoomus r.p.:n (jäljempänä kokoomus), Perussuomalaiset r.p.:n (perussuomalaiset), Suomen Keskusta r.p.:n (keskusta) ja Suomen Sosialidemokraattinen Puolue r.p.:n (SDP) eduskuntavaaliohjelmat. Aineistomme kattaa mainittujen puolueiden eduskuntavaaliohjelmat vuosilta 1991-2019. Perussuomalaiset r.p. perustettiin vuoden 1995 toukokuussa ja puolue osallistui ensimmäistä kertaa eduskuntavaaleihin vuonna 1999, joten sen osalta aineisto kattaa puolueen eduskuntavaaliohjelmat vuosilta 1999-2019. Olemme tarkastelleet puolueiden eduskuntavaaliohjelmissaan esittämiä tulkintoja kansalaisuudesta ja analysoineet niitä kriittisen diskurssianalyysin näkökulmasta. Vaikka eduskuntavaaliohjelmat ovat neljän vuoden välein toteutuva puolueiden "ulostulo" sekä äänestäjien, omien jäsenten että kilpailevien puolueiden suuntaan, niitä on tutkittu Suomessa vähemmän kuin hallitusohjelmia, työryhmien mietintöjä ja raportteja tai eduskuntakeskusteluja (mm. Kananen 2008; Kantola 2006; Saarinen ym. 2014). Aiemman eduskuntavaaliohjelmatutkimuksen perusteella vaaliohjelmissa käytävä puhe hyvinvoinnista on talous- ja kilpailukykypainotteisia (Karjalainen ym. 2017). Lapset ja vanhukset (Karjalainen ym. 2021/tulossa) näyttäytyvät vaaliohjelmissa pääsääntöisesti passiivisina julkisten palveluiden kohteena; ohjelmissa lasten vähäinen toimijuus sijoitetaan tulevaisuuteen ja vanhusten menneeseen. Eduskuntavaaliohjelmien kansalaisuustulkintoja ei ole aikaisemmin tutkittu.

Vaalit ovat tapahtuma, jota voi tarkastella sekä viestintänä että toimintana ja tekemisenä - politikointina. Kun vaaleja tarkastellaan politiikan tutkimuksen näkökulmasta, puolueiden välillä voidaan tulkita syntyvän kamppailu tilanteiden määrittämisestä, niiden muuttamisesta tai 
säilyttämisestä. (Palonen 1987, 306.) Tulkitsemme, että eduskuntavaaleihin kytkeytyvät puoluekohtaiset eduskuntavaaliohjelmat ovat yksi areena, jolla puolueet käyvät kansalaisuuden määrittämisestä argumentoitua keskustelua. Määrittelemällä kansalaisia ja kansalaisuutta tuotetaan myös ne kansalaisten tarpeet, joihin julkisen vallan tulee vastata. Puolueiden eduskuntavaaliohjelmissa tuotettujen kansalaisuuden käsitteiden avulla määritellään siten politiikan sisältöjä ja kehityssuuntia.

Artikkelimme alkaa muuttuvan kansalaisuuden käsitteen tarkastelulla. Toisessa teorialuvussa taustoitamme puolueiden ideologisia kansalaisuuskäsityksiä ja niiden muutoksia. Tämän jälkeen määrittelemme käyttämämme tutkimusmenetelmän eli kriittisen diskurssianalyysin ja kuvaamme aineiston. Tämän jälkeen siirrymme kahteen tuloslukuun. Lopuksi seuraavat johtopäätökset ja pohdinta.

\section{KANSALAISUUDEN MUUTTUVA KÄSITE}

Nykyaikainen länsimainen kansalaisuus juontaa juurensa kansallisvaltioon kuulumiseen ja yksilöille kohdennettuihin oikeuksiin ja velvollisuuksiin (Johansson 2010). Suomessa kansalaisuuden käsitejärjestelmää alettiin jo 1700-luvulta alkaen rakentamaan omien, suomalaisten ehtojen varaan (Stenius 2003, 310, 312, 321), joskin suomenkielinen kansalaisen käsite ja kansalaisdiskurssi vakiintuivat vasta 1820-luvulla (emt., 314-315). Suomessa kansalaisen (myös pitäjien ja maaseudun asukkaiden) katsottiin kuuluvan kansaan, kansakuntaan ja yhteiskuntaan; kansalaisuus käsitteenä alkoi tarkoittaa suomalaista (emt., 321-322).

Kansanvallan käsite ilmaantui Suomessa puolueiden puolueohjelmiin 1800- ja 1900-lukujen vaihteessa, mutta koki varsinaisen nousukauden vuosina 1918-1945. Maalaisliitolla (nyk. keskusta) kansanvalta nousee vahvana esiin vuoden 1921 ohjelmassa ja SDP:1lä vuoden 1930 ohjelmasta lähtien, mutta suhtautuminen kansanvaltaan on SDP:llä ristiriitaisempaa kuin maalaisliiton ohjelmissa. Kokoomus alkaa sen sijaan puhua kansanvallasta vasta 1950-luvulla. Kansanvaltakeskustelussa on kyse siitä, kenelle vallan tulee kuulua Suomessa, sekä tämän vallan legitimoinnista. Kansanvallan käsitteen avulla jäsennettiin 1800-luvun lopulta muun muassa menettelytapoja ja säätyoikeuksien purkamista ja tasavertaisuutta. "Kansanvalta" toimii näin ollen argumenttina politiikan teossa. (Hyvärinen 2003, 83-84, 86-88.)

Demokratian käsite tuli lopullisesti kielenkäyttöön Suomessa toisen maailmansodan jälkeen. Sekä kansanvallan että demokratian käsitteet ovat molemmat olleet politiikan teon välineitä ja niiden korostus on vaihdellut poliittisten suhdanteiden mukaan. (Emt., 83.) Demokratian ja kansanvallan voi katsoa kietoutuvan yhteen käsitteinä: demokratian toimivuuden kriteeri on, että eliittien ja kansalaisten käsitys kansanvaltaisesta poliittisesta järjestelmästä ovat tarpeeksi yhtenevät (Ruostetsaari ja Borg 2004, 147). 1980-luvulta eteenpäin keskustan, SDP:n ja kokoomuksen ohjelmat ovat samankaltaistuneet suhteessa kansanvaltaan ja demokratiaan (Hyvärinen 2003, 95).

Toisen maailmansodan jälkeen kansalaisen poliittisia ja sosiaalisia oikeuksia sekä velvollisuuksia koskevaan ajatteluun vaikutti T.H. Marshallin sosiaalisen kansalaisuuden idea. Marshallilainen ajattelu muotoili osaltaan modernin hyvinvointivaltion ydinajatusta. (Esping-Andersen 
1990; Häikiö ym. 2011; Johansson 2010; Kokkonen 2004; Marshall 1950.) Tällä oli vaikutuksia myös suomalaisen hyvinvointivaltiomallin kehittymiseen 1950-luvulta alkaen. Hyvinvointivaltiomallin keskeisimpiä periaatteita on universalismi, joka määrittelee juuri kansalaisen oikeuksia ja velvollisuuksia (esim. Esping-Andersen 1990). Lisäksi kansalaisten perusoikeuksien sisällyttäminen valtiosääntöön 1900-luvun alkupuolella ja ihmisoikeussopimusten laatiminen 1900-luvun loppupuolella vaikuttivat tulkintaan kansalaisten asemasta: yksilö ei olekaan enää valtiota, vaan valtio yksilöä varten (Sipponen 2000, 69).

Kansalaisuutta ilmaistaan ajassa ja paikassa (Lister 2003, 3). Alasuutarin (2006, 49, 57-58, 63) mukaan 1980-luvun alusta lukien suomalaisessa kansalaispuheessa on tapahtunut muutoksia. Uudessa puhetavassa korostuvat virkavaltaisuuden ja byrokraattisuuden sijaan palveluiden, asiakkaan ja tavallisen kansalaisen näkökulma. Muutosta voi luonnehtia uusliberalistiseksi. Hyvinvointivaltion hallinnan tavassa kansalaisuus määrittyi solidaarisuuden, turvallisuuden tunteen ja hyvinvoinnin kautta. Sen sijaan uusliberalismissa ihannekansalainen on vastuullisesti toimiva, vapaa tekemään rationaalisia valintoja ja harjoittamaan aktiivista itsehallintaa sekä toimimaan yrittäjämäisesti. (Rose 1996.) Uusliberalismia edistäneet lainmuutokset, uudet puhetavat ja käytännöt ovat muuttaneet käsitystä hyvinvointivaltiosta suuntaan, jossa korostuu kilpailutalouden logiikka. Käsitys kansalaisen ja valtion suhteesta on muuttunut: keskeisintä onkin valtion hyvinvointi, mihin tarvitaan hyvinvoivia kansalaisia. (Saarinen ym. 2014.)

Kansalainen on saanut myös uusia velvoitteita: suomalainen sosiaalipolitiikka on muuttunut yksilön aktiivista vastuunottoa korostavaksi (Julkunen 2001; Kananen 2008; Siisiäinen ym. 2014, 89). Usein nähdään, että 1900-luvun alun "holhokki-kansalaisesta" on siirrytty 1900-luvun lopun asiakas-, kuluttuja- ja oikeussubjektikansalaisuuteen (Harjula 2015, 356). Valtio näyttäytyy enenevästi valmentajana, joka motivoi ja kannustaa "henkilöstöään" eli kansalaisiaan entistä parempiin suorituksiin. Omaa tahtoa ilmaisevan kansalaisen tilalle on astunut aktiivikansalainen, ja politiikan tavoitteena on rakentaa ohjaus- ja kannustinjärjestelmä, joka opastaa häntä oikeaan suuntaan. (Kantola 2006, 169-173.) Aktiivikansalaisen lisäksi ihannekansalainen on toimelias ja ottaa vastuuta siitä, että hyvinvointivaltion palvelut voidaan jatkossakin mahdollistaa kaikille kansalaisille (Koskinen ja Saarinen 2019). Ihmisiä pyritään muuttamaan niin, että he sopivat markkinaehtoisen yhteiskunnan tarpeisiin. Tämä on johtanut siihen, että aktiivisen yhteiskunta- ja sosiaalipolitiikan sijaan painotetaan sosiaalityötä, terapiaa ja psykologiaa, joiden tavoitteena on muokata ja ohjata yksilöä (kansalaista), ei niinkään yhteiskuntaa (Silvasti ym. 2014, 13). Taustalla vaikuttavat talouspolitiikkaan liittyvät "välttämättömyyshokemat", jotka kuuluvat markkinafundamentalismiin: kansalaisille vakuutellaan, ettei markkinaliberalismille ole vaihtoehtoja (Lappalainen 2017, 354).

Poliittiset ja sosiaaliset oikeudet sekä velvollisuudet muodostavat yksilölle niin sanotusti täyden kansalaisuuden, johon sisältyy formaalin kansalaisuuden lisäksi henkinen yhteys muihin ihmisiin, identiteetti ja sitoutuminen yhteisön arvoihin (Solomos 2014). Täyteen kansalaisuuteen voidaan liittää myös kansalaisten osallisuuden ja toimijuuden mahdollisuudet yhteiskunnassa (ks. Hvinden ja Johansson 2007; Häikiö ym. 2011, 241; Matthies 2017). Virallinen, formaali kansalaisuus on juridinen status, joka takaa yksilölle kansalaisen perusoikeudet. Formaali kansalaisuus ei kuitenkaan aina tuota täyttä kansalaisuutta. Esimerkiksi vammaisilla ihmisillä ei välttämättä ole samanlaisia oikeuksia kuin ei-vammaisilla yksilöillä tai sukupuoli voi vaikuttaa yksilön oikeuksiin ja velvollisuuksiin (Lister 2003, 6; Ronkainen 2009). Suomessa esimerkiksi 
asevelvollisuus ei kohtele nais- ja mieskansalaisia samalla tavalla. Nämä kaksi kansalaisuuden näkökulmaa - oikeudet ja velvollisuudet sekä formaali, juridinen kansalaisuus - kietoutuvat yhteen. Ylipäätään kansalaisen oikeudellinen määritteleminen on ongelmallista: miten tai kuka voi päättää ketkä kuuluvat kansalaisuuden piiriin? Tätä päätöstä ei voi tehdä esimerkiksi äänestämällä, sillä ensin pitäisi määritellä ketkä ovat kansalaisia ja saavat äänestää. (Lagerspetz 2018, 277.)

Tässä tutkimuksessa olemme kiinnostuneita kansalaisen ja valtion välisestä oikeudellisesta siteestä. Lisäksi tarkastelemme kansanvallan suhdetta yksilön poliittisiin oikeuksiin ja valtion velvollisuuksiin. Nämä kaksi ovat keskeisiä näkökulmia tulkittaessa kansalaisuutta (ks. Kananen ym. 2018; Ronkainen 2009, 48-49).

\section{PUOLUEIDEN IDEOLOGIAT KANSALAISUUSKÄSITYSTEN TAUSTALLA}

Tarkastelemme puolueiden eduskuntavaaliohjelmien kansalaisuustulkintoja pohjoismaisen demokratiakäsityksen ja hyvinvointivaltiomallin muutoksen viitekehyksessä. Jokaisella puolueella on oma identiteettinsä, omat juurensa ja aatteelliset lähtökohtansa (Paloheimo ja Wiberg 1997; Paloheimo ja Sundberg 2005). Vaikka jokainen puolue on omaksunut omat aatteensa, jotka ovat lähtökohtaisesti ristiriitaisia keskenään, se ei ole Suomessa ollut este koherentin hyvinvointivaltiomallin rakentamiselle toisen maailmansodan jälkeen. Suomalainen hyvinvointivaltiomalli on rakennettu pitkälti vasemmistopuoluevetoisesti (esim. Outinen 2017), mutta myös muut puolueet ovat olleet sitoutuneita sen kehittämiseen. Hyvinvointivaltion voi määritellä "diskurssiksi, joka yhdistää joukon ideoita, tavoitteita, järjestelmiä, organisaatioita, hallintoa, rahoitusta, politiikkaa ja poliitikkoja” (Julkunen 2017, 32). Toisen maailmansodan jälkeisiä vuosikymmeniä 1980-luvulle saakka voi luonnehtia hyvinvointivaltion rakentamis- ja laajenemisvaiheena (emt., 44).

1990-luvun lama toi hyvinvointivaltiokehitykseen katkoksen: hyvinvointivaltion kehityssuunnasta on käyty 1990-luvun alusta ideologista kamppailua, jossa kehityksen suuntaa määrittää markkinoiden merkityksen vahvistuminen ja julkisen sektorin aseman väheneminen (esim. Julkunen 2001; 2017). Tulkitsemme, että hyvinvointivaltion suunnasta kamppaillaan yhä: vaikka Suomelle on muodostunut identiteetti pohjoismaisena hyvinvointivaltiona, se ei ole enää itsestäänselvyys. Toiset pyrkivät kasvattamaan markkinoiden merkitystä ja toiset säilyttämään hyvinvointivastuuta ja -tehtäviä julkisella hallinnolla (ks. Möttönen 2009, 60).

Kuten johdannossa totesimme, tulkinnat kansalaisuudesta ohjaavat yhteiskuntapolitiikan tekemistä ja sisältöä. Lisäksi on huomionarvoista, että Suomen kaltaisessa hyvinvointivaltiossa yhteiskuntapolitiikka konkretisoituu kansalaisten suuntaan usein hyvinvointipalvelujärjestelmänä. Matthies $(2017,151)$ toteaakin oivallisesti, että "kansalaisten arjen yhteys poliittiseen järjestelmään konkretisoituu hyvinvointipalveluiden kautta". Suurimmat eduskuntapuolueet edustajineen ovat avainasemassa määriteltäessä kansalaisuutta, kansalaisille suunnattujen hyvinvointipalveluiden sisältöjä tai esimerkiksi palvelujärjestelmän järjestämis- ja rahoitusvastuita - puolueet myös mobilisoivat kansalaisia äänestäjinä ja puolueiden jäseninä (Karvonen $2014,1)$. Tästä syystä on tärkeää tutkia miten puolueet määrittelevät kansalaisten oikeuksia ja velvollisuuksia ja toisaalta valtion ja kansalaisen oikeudellista sidettä. Puolueiden laatimat eduskuntaohjelmat ovat relevantti aineisto tarkastella näitä kysymyksiä. Aiemmasta tutkimuksesta 
tiedetään, että kunkin puolueen kansalaisuuskäsitys on yhteydessä puolueen ideologiaan (ks. Hyvärinen 2003, 83-100). Tässä tutkimuksessa pyrimme saamaan selville eduskuntavaaliohjelmien tutkimisen kautta, minkälaisia mahdollisia ideologisia eroja puolueiden kansalaisuusdiskursseissa on havaittavissa 1990-luvun alusta lähtien: Eroja voidaan saada selville nimenomaan puolueiden laatimia vaaliohjelmia tutkimalla, ei esimerkiksi hallitusohjelmia tarkastelemalla. Eduskuntavaaliohjelmissa puolueet linjaavat omia näkemyksiään ja tekevät ideologisia valintoja suhteessa kansalaisuuteen.

Taulukossa 1 on esitetty Suomen neljän suurimman puolueen perustamisvuosi, kuvattu lyhyesti puolueiden ideologiset lähtökohdat, kuvattu puolueiden kannatus vuosien 1991-2019 eduskuntavaaleissa sekä puolueiden jäsenmäärät vuosina 1995 ja 2018. Näiden perustietojen lisäksi taulukossa on kuvattu puolueiden kansalaiskäsitykset yleisellä tasolla taustoittamaan tutkimuksemme kansalaiskäsitysten tarkastelua. Painopiste tässä tutkimuksessa on kuitenkin tutkia nimenomaisesti puolueiden kansalaisuuskäsityksiä suhteessa suomalaisesta hyvinvointivaltiosta käytävään kamppailuun. 
Taulukko 1. Suomen neljä suurinta puoluetta (aakkosjärjestyksessä),
puolueiden perusideologia, kannatus ja jäsenmäärä sekä kansalaisuuskäsitys.

\begin{tabular}{|c|c|c|c|c|c|}
\hline Puolue & $\begin{array}{l}\text { Puolueen perustamis- } \\
\text { vuosi (Mickelsson } \\
\text { 2015) }\end{array}$ & Puolueen ideologiasta & $\begin{array}{l}\text { Puolueen } \\
\text { kannatus } \\
\text { vuosien 1991- } \\
2019 \text { eduskunta- } \\
\text { vaaleissa (Isotalo } \\
\text { ym. 2019) } \\
\text { prosenttia }\end{array}$ & $\begin{array}{l}\text { Puolueen } \\
\text { jäsenmäärä } \\
\text { vuosina } 1995 \text { ja } \\
2018 \text { (Koivula } \\
2019,41)\end{array}$ & $\begin{array}{l}\text { Puolueen } \\
\text { kansalaisuuskäsitys }\end{array}$ \\
\hline $\begin{array}{l}\text { Kansallinen Kokoomus } \\
\text { r.p. }\end{array}$ & 1918 & $\begin{array}{l}\text { Kokoomus korostaa olevansa } \\
\text { aatepuolue, eikä rajaa } \\
\text { toimintaansa minkään tietyn } \\
\text { yhteiskuntaluokan etujen } \\
\text { ajamiseen (Mickelsson 2015, } \\
\text { 76; Paloheimo \& Sundberg } \\
\text { 2005). }\end{array}$ & $\begin{array}{l}1991: 19,3 \\
1995: 17,9 \\
1999: 21,0 \\
2003: 18,6 \\
2007: 22,3 \\
2011: 20,4 \\
2015: 18,2 \\
2019: 17,0\end{array}$ & $\begin{array}{l}47000 \\
34000\end{array}$ & $\begin{array}{l}\text { Liberalistinen } \\
\text { kansalaisuuskäsitys: } \\
\text { ihmisen tulee itse saada } \\
\text { päättää itseään koskevista } \\
\text { asioista (ks. Paloheimo \& } \\
\text { Wiberg 1997, 116-117). }\end{array}$ \\
\hline $\begin{array}{l}\text { Perussuoma- } \\
\text { laiset r.p. }\end{array}$ & 1995 & $\begin{array}{l}\text { Perussuomalaisilla on vahva } \\
\text { protestipuolueen leima } \\
\text { ja kannattajia yhdistää } \\
\text { tyytymättömyys päättävässä } \\
\text { asemassa olevia kohtaan. } \\
\text { Perussuomalaisten ideologissa } \\
\text { linjauksissa korostuvat } \\
\text { kansa, isänmaallisuus ja } \\
\text { eliitinvastaisuus. (Mickelsson } \\
\text { 2015, 315-316, Paloheimo \& } \\
\text { Sundberg 2005; Ylä-Anttila \& } \\
\text { Ylä-Anttila 2015.) }\end{array}$ & $\begin{array}{l}1999: 1,0 \\
2003: 1,6 \\
2007: 4,1 \\
2011: 19,1 \\
2015: 17,7 \\
2019: 17,5\end{array}$ & $\begin{array}{l}2000 \text { (vuoden } 2004 \\
\text { jäsenmäärä) } \\
11000\end{array}$ & $\begin{array}{l}\text { Käsitys aidosta kansasta, } \\
\text { jonka tulisi pitää valtaa ja } \\
\text { hallita (Norris ja Inglehart } \\
2019,4) \text {. }\end{array}$ \\
\hline Suomen Keskusta r.p. & $\begin{array}{l}1906 \text { (Suomen } \\
\text { Maalaisväestön Liitto } \\
\text { ja Etelä-Pohjanmaan } \\
\text { Nuorsuomalainen } \\
\text { Maalaisliitto } \\
\text { perustettiin } 1906 \\
\text { agraaripuolueiksi ja } \\
\text { ne yhdistyivät vuonna } \\
\text { 1908.) }\end{array}$ & $\begin{array}{l}\text { Keskusta luettiin alun perin } \\
\text { porvaripuolueiden ryhmään - } \\
\text { pääpainotuksena maaseutua } \\
\text { koskevat asiat - mutta } \\
\text { 1970-luvulta alkaen keskusta } \\
\text { on kehittynyt yleispuolueeksi } \\
\text { (Mickelsson 2015, 68-69; } \\
\text { Paloheimo \& Sundberg 2005). }\end{array}$ & $\begin{array}{l}1991: 24,8 \\
1995: 19,8 \\
1999: 22,4 \\
2003: 24,7 \\
2007: 23,1 \\
2011: 15,8 \\
2015: 21,2 \\
2019: 13,8\end{array}$ & $\begin{array}{l}257000 \\
102772\end{array}$ & $\begin{array}{l}\text { Yhdistelmä liberalistista, } \\
\text { negatiivisia } \\
\text { kansalaisoikeuksia } \\
\text { korostavaa näkemystä sekä } \\
\text { sosiaalisten oikeuksien } \\
\text { korostamista (ks. } \\
\text { Paloheimo \& Wiberg 1997, } \\
\text { 116-117). }\end{array}$ \\
\hline $\begin{array}{l}\text { Suomen Sosialidemo- } \\
\text { kraattinen Puolue r.p }\end{array}$ & 1899 & $\begin{array}{l}\text { SDP perustettiin } 1899 \text { ajamaan } \\
\text { työväen (teollisuustyöväestö, } \\
\text { torpparit ja tilaton } \\
\text { väestö) asiaa (Koiranen } \\
\text { ym. 2019; Mickelsson 2015, } \\
\text { 60-61, 67; Stenius 2003, } \\
\text { 351) ja työväenpuolueen } \\
\text { perinne näkyy SDP:n } \\
\text { kannattajakunnassa vieläkin } \\
\text { (Westinen 2016, 268). SDP:n } \\
\text { voidaan kuitenkin todeta } \\
\text { keskiluokkaistuneen: } \\
\text { puolue on muun muassa } \\
\text { siirtynyt painottamaan } \\
\text { yksityissektorivetoista } \\
\text { työllisyyttä, tavoitellut } \\
\text { keskiluokan äänestäjïä ja } \\
\text { hyväksynyt markkinatalouden } \\
\text { (0utinen 2017). }\end{array}$ & $\begin{array}{l}1991: 22,1 \\
1995: 29,3 \\
1999: 22,8 \\
2003: 24,5 \\
2007: 21,4 \\
2011: 19,1 \\
2015: 16,5 \\
2019: 17,7\end{array}$ & $\begin{array}{l}70000 \\
38314\end{array}$ & $\begin{array}{l}\text { Kansalaisuuskäsitys } \\
\text { rakentuu monelta osin } \\
\text { vastakkainasettelulle } \\
\text { työnantajien/porvareiden } \\
\text { ja työntekijöiden } \\
\text { välille (Mickelsson } \\
\text { 2015, 427) sekä nojaa } \\
\text { kansalaisten sosiaalisten } \\
\text { perusoikeuksien } \\
\text { korostamiseen (Paloheimo } \\
\text { \& Wiberg 1997, 117). }\end{array}$ \\
\hline
\end{tabular}


Tässä tutkimuksessa tarkasteltavista puolueista keskusta, kokoomus ja SDP ovat perinteisiä intressipuolueita, mutta yleispuolueistuneet. Yleispuolueistuminen tarkoittaa sitä, että aiemmin leimallisesti luokkapuolueiksi nimetyt puolueet ovat sittemmin tavoitelleet laajempaa kannattajakuntaa luokkansa ulkopuolisista äänestäjistä (Katz 2013; Koiranen ym. 2019, 311). Sen sijaan perussuomalaiset mielletään niin sanotuksi uudeksi puolueeksi, joka on syntynyt yleisestä yhteiskunnallisesta politiikkakysymysten muutoksesta. Länsimaissa on syntynyt uuskonservatiivisia, nimenomaan populistisia liikkeitä, jotka vastustavat muun muassa postmateriaalisten arvojen leviämistä. Näille oikeistopopulisteille suosittuja teemoja ovat muun muassa nationalismi ja maahanmuuttovastaisuus. (Karvonen 2014; Koiranen ym. 2019, 310-311; Norris ja Inglehart 2019, 44-49.) Sosioekonominen ulottuvuus on edelleen ideologisesti merkittävä jakolinja, mutta lisäksi globalisaatio, siirtolaisuus, ilmastonmuutos ja yksilön vapaudet jakavat poliittista kenttää. Suomessa arvoliberalismi ja -konservatismi sekä EU-kysymykset ovat keskeisiä uusia jakolinjoja. (Mannerström ym. 2020; Mattila ja Raunio 2006; Norris ja Inglehart 2019.)

\section{TUTKIMUKSEN TAVOITE, TUTKIMUSKYSYMYS JA AINEISTO}

Tutkimuksen tavoitteena on tehdä näkyväksi millaisia ideologisia valintoja neljä suurinta puoluetta ovat tehneet eduskuntavaaliohjelmissaan suhteessa hyvinvointivaltiokansalaisuusdiskursseihin vuodesta 1991 alkaen. Olemme kiinnostuneita siitä, miten puolueet käyttävät ohjelmissaan kansalaisuutta määritellessään politiikkaansa. Vaikka eduskuntavaaliohjelmissa ilmaistu ei suoraan toteudu politiikan tekemisessä, kansalaisuuskäsitykset ovat merkityksellisiä siksi, että ne ohjaavat ja normittavat yhteiskuntapolitiikan tekemistä ja sisältöä. Tutkimuksemme tarkennetut tutkimuskysymykset ovat: 1) minkälaisia ideologisia eroja neljän suurimman puolueen eduskuntavaaliohjelmissa (vuosina 1991-2019) tuotetaan suhteessa kansalaisten poliittisiin ja sosiaalisiin oikeuksiin ja velvollisuuksiin sekä 2) millaisia perusteluja käyttäen kansalaisen ja valtion välinen oikeudellinen side ja legitimiteetti vaaliohjelmissa tuotetaan? Tarkastelemme tutkimuskysymyksiä pohjoismaisesta hyvinvointivaltiomallista käytävän kamppailun viitekehyksessä.

Tutkimuksen aineisto koostuu keskustan, kokoomuksen, perussuomalaisten ja SDP:n vuosien 1991-2019 eduskuntavaaliohjelmista. Aineiston ajallinen rajaus perustuu 1990-luvun alkuun ajoittuvan taloudellisen laman sekä kansainvälisen politiikan (Neuvostoliiton romahdus ja Euroopan integraatio) muutosten laajuuteen suomalaisessa taloudellisessa ja poliittisessa toimintaympäristössä. Julkusen $(2017,10)$ mukaan 1990-luku oli dramaattinen ja Suomen suuntaa muuttanut vuosikymmen. Voidaan tulkita, että 1990-luvun alusta käynnistyi uusi poliittinen aikakausi, jossa on painottunut muutos aatteellisesti himmenevästi hyvinvointivaltiosta hyvinvointiyhteiskuntaan (Eräsaari 2000, 37). Hyvinvointivaltion paradigmaa on ajateltu uudestaan, mikä on tarkoittanut esimerkiksi sosiaalimenojen ja työvoimakustannusten madaltamista talouden vauhdittamiseksi ja yritysten kilpailukyvyn säilyttämiseksi, sosiaalipolitiikan kannustimien luomista sekä ohjattua kilpailua terveydenhuoltomarkkinoilla (Julkunen 2017, 10).

Aineistoksi on valittu vuosien 2011, 2015 ja 2019 eduskuntavaalien tulosten pohjalta neljän suurimman puolueen vaaliohjelmatekstit. Nämä tekstit ovat poliittisen eliitin kirjoittamia 
(ks. lisää eduskuntavaaliohjelmien kirjoitusprosessista Karjalainen ym. 2017), joilla pyritään vaikuttamaan äänestäjiin ja perustelemaan heille puolueen linjaukset. Kokonaisuudessaan aineisto sisältää 151086 sanaa ja jakautuu eri puolueiden välillä seuraavasti: keskusta 44 412, kokoomus 21067, perussuomalaiset 32533 ja SDP 53074 sanaa.

\section{TUTKIMUSMENETELMÄT}

Sosiaalisessa konstruktionismissa vallitsee dialektinen jännite: samalla kun yhteiskunta ymmärretään ihmisten toiminnan tuotteena, on myös nähtävä, miten yhteiskunta tuottaa siinä toimivat ihmiset (Ahponen 2001, 52). Konstruktionismissa korostuu ajatus, että termit, joiden kautta maailmaa ymmärretään, ovat historiasta nykyaikaan rakentuneen vuoropuhelun tulosta (Gergen 1985; Hacking 2009, 102-133, 139). Sosiaalinen konstruktionismi tarjoaa välineitä itsestään selvinä esitettyjen väitteiden ideologisten taustaoletusten purkamiseen. Kieli ei ole neutraalia, vaikka se usein objektivoidaan dialogisin ja yhteiskunnallisin käytännöin näyttäytymään inhimillisestä merkityksestä riippumattomana. Kieli myös legitimoi vallitsevien käsitteiden asettajien asemaa. (Virsu 2007, 347.) Politiikka on valtaosaltaan kielen varassa olevaa toimintaa (Mickelsson 2007, 24). Kielenkäytön taustalla olevia ideologisia oletuksia voi purkaa tekemällä näkyväksi itsestään selvänä näyttäytyviä kielellisiä valintoja tai muutoksia. Kuten Freeden (2019) täsmentää: ideologioita ilmaistaan ensisijaisesti kielellä. Diskurssit ovat kommunikatiivista käytäntöä, jotka mahdollistavat ideologian harjoittamisen. Puolueet käyttävät eduskuntavaaliohjelmissaan kielellisiä strategioita eli valitsevat tiettyjä ilmaisuja, sanoja tai painotuksia vaaliohjelmiinsa ja jättävät toisia termejä ohjelmien ulkopuolelle niistä vaieten.

Kriittisessä diskurssianalyysissä voidaan tunnistaa sen tieteiden välinen luonne (Wodak 2005). Sosiaaliset ilmiöt edellyttävät monitieteisyyttä ja monia metodologisia paradigmoja (Wodak ja Mayer 2009, 2). Koska emme tulkitse eduskuntavaaliohjelmia todellisuuden kuviksi, valitsimme kriittisen diskurssianalyysin tutkimuksemme lähestymistavaksi. Artikkelissa seurataan faircloughlaista kriittistä diskurssianalyysiä, jota tuetaan van Dijkin ideologiakriittisemmällä analyysillä. Kriittisen diskurssianalyysin mukaan diskurssit ovat yhteydessä sosiaaliseen toimintaan (Poutanen 2018, 41), näin ollen ymmärrämme diskurssin tekstuaalisena kokonaisuutena ja osana sosiokulttuurisia käytäntöjä, joka rakentaa osaltaan sosiaalista todellisuutta (Pynnönen 2015, 34; Siltaoja ja Vehkaperä 2011). Erityisesti olemme kiinnostuneita argumentaatioista ja keinoista, joilla vaaliohjelmissa konstruoidaan tiettyjä kansalaisuustulkintoja.

Diskurssianalyysiin liittyy vahva oletus merkityksellisen toiminnan kontekstisidonnaisuudesta. Poliittinen kamppailu vaalikentillä on erilainen kansalaisuuden määrittelyn konteksti kuin esimerkiksi oikeussali: kielenkäyttömme, mukaan lukien vaaliohjelmatekstit, eivät ainoastaan kuvaa maailmaa, vaan uusintavat ja muuttavat sosiaalista todellisuuttamme. (Jokinen ym. 2016.) Diskurssit ovat vakiintuneita puhekäytänteitä, jotka osaltaan rakentavat ja tuottavat sitä ilmiötä, jota ne kuvaavat (Jokinen ym. 2016, 26; Siltaoja ja Vehkaperä 2011, 209).

Kriittinen diskurssianalyysi pyrkii tunnistamaan, tulkitsemaan ja selittämään kielenkäytön ja yhteiskunnan sosiaalisten rakenteiden suhdetta. Se keskittyy tapaan, jolla diskurssit säätelevät, 
vahvistavat tai haastavat vallankäyttöä ja yhteiskunnallista todellisuutta (van Dijk 2010, 467). Kielenkäytössä on aina mukana mahdollisuus sosiaaliseen hyväksyntään tai hylkäämiseen; se rakentaa todellisuutta, jossa jokin vaihtoehto näyttäytyy toista hyväksyttävämpänä (Fairclough 2010, 57). Kriittinen diskurssianalyysi antaa mahdollisuuden tarkastella esimerkiksi epätasaarvoisia valtasuhteita, kuten sosiaalisia luokkia tai kulttuurisia enemmistöjä ja vähemmistöjä (Wodak ja Fairclough 1997, 258). Diskurssit voivat epäsuorasti ja tahattomasti vaikuttaa yksilöiden mielipiteisiin, asenteisiin ja ideologioihin. Kriittisen diskurssianalyysin avulla pyritään selvittämään myös näitä, mahdollisesti tiedostamattomia, kielenkäytön seurauksia (van Dijk 2010).

Diskurssianalyysissä tunnistetut diskurssit liitetään ja muokataan osaksi aikaisempia puhetapoja interdiskurssiivisesti (Fairclough 2003). Suomessa tällä hetkellä yhteiskuntapoliittisesti relevantteja teemoja, joiden osana käydään neuvottelua kansalaisuuden sisällöstä, ovat muun muassa hyvinvointi (Berg ja Salasuo 2016; Häikiö ym. 2011; Saarinen ym. 2014; Karjalainen ym. 2017), maahanmuutto (Ronkainen ym. 2006; Vuori 2015; Pirkkalainen ym. 2016; Kananen ym. 2018), lasten ja vanhusten kansalaisuus (Alanen 2009; Karjalainen ym. 2021/tulossa; Nikander ja Zehner 2006) vammaisten kansalaisuus (Nykänen ym. 2018), seksuaalivähemmistöt (Kangasvuo 2014) sekä yrittäjyys (Koskinen ja Saarinen 2019). Tutkimuksemme osallistuu tähän yhteiskunnalliseen ja poliittiseen keskusteluun kansalaisuudesta.

Kansalaisuutta kuvaavien tekstikatkelmien tunnistamiseksi luimme mainittujen puolueiden eduskuntavaaliohjelmat vuosilta 1991-2019 useampaan kertaan. Aineiston kokonaislukemisen jälkeen haimme kansalaisuuteen liittyviä tekstikatkelmia aineistosta kansa* ${ }^{*}$ hakusanalla. Näillä kahdella menetelmällä löysimme ja rajasimme aineistosta tarkasteluun tekstikatkelmat, joissa puhutaan kansalaisuudesta. Tutkimuskysymyksemme mukaisesti keskitimme huomiomme tekstikatkelmiin, jossa puolueet tekevät ideologisia valintoja käyttäen tietynlaisia puhetapoja ja ilmaisuja kansalaisten oikeuksista ja velvollisuuksista sekä valtion ja kansalaisen oikeudellisesta suhteesta. Lisäksi analyysimme keskittyi tarkastelemaan näitä tekstikatkelmia osana suomalaisesta hyvinvointivaltiomallista käytävää kamppailua, eli tutkimme hyvinvointivaltiokansalaisuusdiskursseja.

Tarkastelimme kielen käyttökontekstia, jännitteitä, ideologisia painotuksia (ks. diskurssin ja ideologian suhteesta aiemmin tässä artikkelissa) sekä analysoimme seurauksia, joita puolueiden kielenkäytöllä on. Kiinnitimme huomiomme puolueiden kielenkäytön reunaehtoihin, normeihin ja seurauksiin (esim. Jokinen ym. 2016, 26; Siltaoja ja Vehkaperä 2011, 209). Teimme analyysia luokitellen tekstikatkelmia koherenteiksi, yhdenmukaisiksi kokonaisuuksiksi, joissa kansalaisuudesta puhutaan samoin käsittein ja sanavalinnoin. Kun eduskuntavaaliohjelmissa puhutaan kansalaisuudesta, puhutaan esimerkiksi hyvinvoinnista, palveluista, turvallisuudesta, vastuusta, kuluttamisesta, yrittäjyydestä, veteraaneista, koulutuksesta sekä vallasta ja kansalaisen asemasta.

Aineistosta kootut tekstikatkelmat kokosimme taulukko-ohjelmaan, jolloin pystyimme paikallistamaan aineistosta kansalaisuuteen liittyviä puhetapoja. Tuloslukuun valitsimme 18 tekstilainausta, jotka mahdollisimman monipuolisesti ja kattavasti tuovat esille kansalaisuuteen liittyvät diskurssit eduskuntavaaliohjelmissa. 


\section{KANSALAISUUDEN DISKURSSIT EDUSKUNTAVAALIOHJELMISSA}

Eduskuntavaaliohjelmat ovat luonteeltaan narratiivisia. Esimerkiksi kokoomuksen vuosien 2007 ja 2011 vaaliohjelmat ovat tarinamuotoon kirjoitettuja kertomuksia roolihenkilöineen. Torkki $(2014,223)$ toteaakin, että tarinallisuus on paljon vaikuttavampaa kielenkäyttöä poliittisessa puheessa kuin faktat ja teoria. Ohjelmissa ei viitata juurikaan tilastoihin tai tutkimuksiin (ks. Karjalainen ym. 2021/tulossa). Kokonaisuutena puolueiden vaaliohjelmissa puhutaan kansalaisuudesta varsin yleisellä tasolla, eikä kansalaisuutta määritellä. Käsitteiden määrittelemättömyys on poliittisen puheen kontekstissa hyvin yleistä (Koiranen ym. 2019, 325)1. Soinin (2020) mukaan populistien puhuessa kansasta he voivat tarkoittaa "kaikkia ihmisiä tai tavallisia ihmisiä": ne, jotka eivät ole eliitin jäseniä, ovat tavallisia ihmisiä.

Aineistosta oli tunnistettavissa kolme tutkimuskysymyksiimme vastaavaa diskurssia. Kansalaisen poliittisiin ja sosiaalisiin oikeuksiin ja velvollisuuksiin liittyen tunnistimme kaksi diskurssia: palveluiden kohteena olevan kansalaisen ja omatoimisen kansalaisen diskurssit. Kansalaisen ja valtion oikeudelliseen siteeseen ja legitimiteettiin liittyen tunnistimme kansanvallan diskurssin.

Yhteensä tutkimuskysymyksen mukaisesti tunnistettuja kansalaisuuden tekstikatkelmia aineistossa on 281. On huomionarvoista, että vaaliohjelmissa esiintyy myös esimerkiksi kuluttajakansalaisuuteen, kansalaistaitoihin ja suomalaiseen kansalaisuusidentiteettiin viittaavaa kansalaisuuspuhetta.

\section{Palveluiden kohteena olevan kansalaisen ja omatoimisen kansalaisen diskurssit}

Tässä luvussa tarkastelemme palveluiden kohteena olevan kansalaisen ja omatoimisen kansalaisen diskursseja. Analyysimme etenee perussuomalaisten vaaliohjelmien analyysistä SDP:n ja keskustan kautta kokoomuksen vaaliohjelmiin. Esitysjärjestys noudattaa ideologista jakoa: perussuomalaisten ohjelmissa painottuu palveluiden kohteena olevan kansalaisen diskurssi ja painotus siirtyy kokoomukseen tultaessa omatoimisen kansalaisen diskurssiin. Kaksi mainittua diskurssia esiintyvät kuitenkin kaikkien neljän puolueen eduskuntavaaliohjelmissa.

Perussuomalaisten eduskuntavaaliohjelmissa painottuu enemmän palveluiden kohteena olevan kansalaisen diskurssi (43 tekstikatkelmaa) kuin omatoimisen kansalaisen (15 tekstikatkelmaa) diskurssi. Puolueen ohjelmissa korostuu valtion ja kansalaisen tiivis, erottamaton suhde, johon liittyy vahvasti pohjoismainen hyvinvointivaltiomalli kansalaisen turvana ja pelastajana. Perussuomalaisille tyypillistä, ja muista puolueista erottavaa, on myös se, että heidän kansalaisuusdiskurssissaan esiintyy EU:n vastaista retoriikkaa (esimerkki 1).

1. Perussuomalaisten mielestä Suomen tulee jatkaa perinteisellä pohjoismaisella hyvinvointipolitiikalla, jossa valtiovalta viime kädessä turvaa jokaiselle kansalaiselle ihmisarvoisen elämän. Nyt pohjoismaista mallia on alettu Suomessa raivata EU:n edustaman köyhäinhoitoyhteiskunnan tieltä. (PS 2011)

Samalla, kun perussuomalaisten eduskuntavaaliohjelma tulkitsee kansalaisuutta vahvasti palveluiden kohteena olemisena, painottuu se, ettei kansalaisen sovi olla liian omatoiminen (esimerkki 2): 
2. Mikäli kansalaisten hyvinvointi halutaan turvata, yhteiskunnan on uskallettava ottaa kantaa monenlaisiin arkisiin seikkoihin, jotka nykyään on jätetty vain kansalaisten oman vastuun varaan riippumatta yksilöllisestä elämäntilanteesta. (PS 2011)

Ajankohtaisessa tutkimuksessa tuodaan voimakkaasti esille "vastuu on teillä itsellänne" -politiikan hegemonisuus 2000-luvun Suomessa (esim. Helne ym. 2004). Tällainen puhetapa ei kuitenkaan ole vallitseva perussuomalaisten eduskuntavaaliohjelmissa, joissa korostuu sen sijasta julkisten palveluiden kautta tapahtuva kansalaisten hallinta. Puolue siis uusintaa näkemystä turvallisesta pohjoismaisesta hyvinvointivaltiokansalaisuudesta tai toisesta näkökulmasta tarkasteltuna valtiojohtoisesta, holhoavasta hallintakansalaisuudesta.

Perussuomalaisten kansalaisuusdiskurssissa palveluiden kohteena oleminen painottuu "uhrikansalaisuuteen" eli kansalaiset nähdään "yhteiskunnan", "valtakoneiston" tai muun määrittelemättömän tahon uhreina:

3.Perussuomalaisten mielestä kansalaisia on viimeisten vuosikymmenten aikana johdettu tietoisesti harhaan, kun yhteiskunta on entistä enemmän vetäytynyt vastuustaan sairauksien ja sosiaalisten ongelmatilanteiden hoitamisessa, ilman että kansalaisille olisi selkeästi ja ennalta viestitetty muutoksista vastuusuhteissa. (PS 2011)

Populismille tyypillisesti puolue vastustaa voimassa olevan edustuksellisen politiikan instituutioita ja käytäntöjä (ks. Müller 2017; Taggart 2000) ja näkee ne lisäksi kansalaisille haitallisiksi. Perussuomalaisten kansalaisuuskäsitys rakentuu eduskuntavaaliohjelmissa vahvalle polarisaatiolle, jossa tavallinen kansa ja eliitti asetetaan vastakkain (ks. Mickelsson 2007; Mickelsson 2015; Norris ja Inglehart 2019; Palonen 2020; Palonen ja Saresma 2017).

4. Kansalaisista etääntynyt valtakoneisto toitottaa kaikissa merkittävissä asioissa, ettei ole olemassa kuin yksi mahdollinen tie ja vaihtoehto - heidän omansa. Tällainen tilanne demokratiassa on mahdoton. Valtakoneisto aliarvioi kansaa ja pitää sitä itsenäisiin valintoihin kykenemättömänä. (PS 2003)

Esimerkissä 4 perussuomalaiset asettavat valtakoneiston ja kansan vastakkain ja syyttävät valtakoneistoa kansan aliarvioimisesta. Esimerkkejä 1, 2, 3 ja 4 vertailemalla voi havaita ristiriidan: toisaalta puolue haluaa kansalaisten olevan turvassa hyvinvointivaltion rakenteiden suojassa, mutta toisaalta he näkevät tämän valtakoneiston uhkana kansalaisten turvallisuudelle. Perussuomalaiset ei esitä mitään arvioita siitä, keiden kaikkien he ajattelevat olevan itsenäisiin valintoihin kykeneviä. Onko esimerkiksi lapsilla tai vanhuksilla, maahanmuuttaneilla tai vammaisilla tällaista kykyä (vrt. Karjalainen ym. 2021/tulossa). Populismille on tyypillistä, että se vaikenee siitä minkälaista politiikka ja mitä päätöksiä pitäisi tehdä. Populistinen diskurssi on kameleonttimaista muokkautuen ideologisilta arvoiltaan ja periaatteiltaan. (Norris ja Inglehart 2019, 4.)

Perussuomalaisten vaaliohjelmissa on niin ikään merkillepantavaa se, miten käsitteitä "valtio" ja "yhteiskunta" käytetään: valtion tehtävänä on turvata kattavasti kansalaisten hyvinvointi ja turvallisuus. Sen sijaan yhteiskunta ottaa kantaa ja ohjaa. Toisin sanoen perussuomalaisten 
jossain määrin paternalistisessa näkemyksessä toimijana ei ole yksiselitteisesti valtio, vaan "yhteiskunta”, mikä hämärtää kansalaisiin kohdistetun vallankäytön konkreettisia mekanismeja. (Ks. Karjalainen ym. 2021/tulossa.) Valtion ja yhteiskunnan sekoittaminen on yleistä paitsi Pohjoismaissa, myös muiden maiden poliittisissa kielissä: valtion ja kuntien muodostamasta kokonaisuudesta saatetaan puhua yleisesti "yhteiskuntana" (Kettunen 2003, 170).

SDP:n vaaliohjelmissa on niin ikään enemmän tekstikatkelmia liittyen palveluiden kohteena olevan kansalaisen diskurssiin (32 tekstikatkelmaa). Kuitenkin omatoimisen kansalaisen diskurssiin liittyviä mainintoja on myös runsaasti: 24 tekstikatkelmaa. SDP kuvaa vaaliohjelmissaan kansalaiset ensisijaisesti palvelujärjestelmän ja julkisen sektorin toimien kohteina, ja vasta toissijaisesti muulla tavoin aktiivisina toimijoina.

5. Kansalaisten turvallisuudesta huolehtiminen on yksi yhteiskunnan päätehtävistä. (SDP 2019)

6. Kaikessa kulttuuri- ja nuorisotoiminnan tukemisessa on kannustettava kansalaisten ja heidän järjestöjensä omaehtoista toimintaa. (SDP 1995)

\section{Kansalaistoimintaa on edistettävä ja sen toimintaedellytyksiä parannettava. (SDP 2007)}

8. Samalla on huolehdittava opetuksen sivistyksellisistä tavoitteista ja aktiivisen kansalaisuuden taidoista. (SDP 2019)

Esimerkki 5 edustaa kuvaavasti "perinteistä" hyvinvointivaltiokansalaisuustulkintaa (ks. Rose 1996): vaikka esimerkissä viitataan käsitteenä yhteiskuntaan, syntyy vahva vaikutelma, että tarkoitetaan valtiojohtoisia toimia, joiden tehtävänä on kansalaisten turvallisuudesta huolehtiminen. Esimerkeissä 6-8 julkinen valta tukee, kannustaa, edistää, luo toimintaedellytyksiä tai huolehtii ja tällaisen julkisen vallan toiminnan katsotaan olevan olennaista kansalaisten aktiivisuuden kannalta. SDP ilmaisee asiat julkisen vallan näkökulmasta ja korostaa kansalaisten omatoimisuuden tukemista ulkopuolelta. SDP:n omatoimisen kansalaisen diskurssi eroaakin keskustan ja kokoomuksen vastaavista; SDP:llä omatoimisuus rakentuu kansalaisyhteiskunnan ja kansalaisjärjestöjen kautta. SDP:n tarkoittama omatoimisuus on valtion/kuntien ja lainsäädännön ohjailun ja vallankäytön piirissä olevaa omatoimisuutta. SDP kuvaa vaaliohjelmissaan kansalaiset ensisijaisesti palvelujärjestelmän ja julkisen sektorin toimien kohteina, ja vasta toissijaisesti muulla tavoin aktiivisina toimijoina. Myöskään SDP:n vaaliohjelmissa ei korostu puhetapa, jossa vastuu yksilön elämästä olisi ihmisillä itsellään tai hänen lähipiirillään (ks. Helne ym. 2004, 17). Kansalaiset nähdään palveluiden kohteina tai valtion järjestämistä toimintamahdollisuuksista hyötyjinä ja esimerkiksi kuluttajakansalaisen tai asiakkaan näkökulmat ohitetaan (ks. Hyssälä ja Backman 2018).

Myös keskustapuolueella painottuu palveluiden kohteena olemisen diskurssi (43 tekstikatkelmaa), joskin mainintoja omatoimisen kansalaisen diskurssiin liittyen on lähes yhtä paljon (37 tekstikatkelmaa). Keskustan kansalaisuustulkinnoissa omatoimisen kansalaisen diskurssi on itsenäisempi valtiosta kuin perussuomalaisilla ja SDP:llä: 
9. Ansiosidonnaisen turvan vakuutusluonne lisää kunkin omaa vastuuta ja vaikutusmahdollisuuksia etuuksiensa tasoon. (Keskusta 1999)

10. Aktiivinen kansalaisuus on merkittävä osa sivistystä. (Keskusta 2011)

11. Väestön ikärakenteenkin muutoksen vuoksi kansalaisia on kannustettava vahvempaan vastuuseen itsestään ja läheisistään. Kansalaisia on kannustettava kehittämään palveluja ja lisäämään vaihtoehtoja myös omin toimin. (Keskusta 2019)

Keskustan ohjelmissa korostetaan itsenäisesti toimivaa kansalaista, mutta omatoimista ja kehittyvää kansalaista ei kuitenkaan ole olemassa ilman (hyvinvointi)valtion rakenteita. Esimerkin 9 mukaisessa työttömyystilanteessa korostetaan ihmisten omaa vastuuta, mutta taustalla on kuitenkin vakuutuspalvelu. Vuoteen 2019 tultaessa keskustan vaaliohjelmista on tulkittavissa omatoimisen kansalaisen diskurssin voimistuminen: esimerkissä 11 viitataan väestön ikärakenteen muutokseen ja kansalaisten vahvempaan vastuuseen itsestään ja läheisistään. Esimerkissä viitataan myös kansalaisten kykenevyyteen kehittää palveluita ja lisätä vaihtoehtoja omin toimin. Keskusta lähenee vuoden 2019 vaaliohjelmapuheellaan kokoomuksen palvelumuotoilun retoriikkaa (kokoomuksen osalta ks. tarkemmin jäljempänä).

Keskustan vaaliohjelmissa - samoin kuin SDP:n ohjelmissa - kansalaisten omatoimisuutta ja aktiivisuutta näyttää leimaavan riittämättömyys; vaikka ihmiset olisivat omatoimisia ja aktiivisia, näitä asioita pitää silti tukea. Tukitoimissa keskeinen toimija on valtio ja erilaiset valtiojohtoiset järjestelmät. Yleisesti neljän puolueen vaaliohjelmissa ei oteta kantaa siihen, milloin riittävä omatoimisuuden tai aktiivisuuden taso olisi saavutettu. Ohjelmista ei myöskään selviä miten ihmisten puuttuva omatoimisuuden taso tai tuen tarve ilmenevät. Se, että valtio näyttäytyy toimijana suhteessa kansalaiseen johtaa väistämättä myös valta-asetelman rakentumiseen: suhde kansalaisen ja valtion välillä on valtion määrittelemien palvelurakenteiden varassa. Rose (1996) toteakin turvallisuuden tunteen ja hyvinvoinnin olevan eräitä hyvinvointivaltion hallinnan tapoja.

Kokoomuksen vaaliohjelmissa esiintyy yhtä monta tekstikatkelmaa liittyen omatoimiseen kansalaisuuden diskurssiin (7) ja palveluiden kohteena olemisen diskurssiin (7). Määrällisesti tekstikatkelmia on vähemmän kuin muilla puolueilla. Kokoomuksen eduskuntavaaliohjelmissa esiintyykin runsaasti muuta kansalaisuuspuhetta, kuten puhetta kuluttajista ja yksityisistä vuokranantajista (kokoomus 1991), työuraa tekevistä naisista (kokoomus 1995) tai osatyökykyisistä (kokoomus 2019).

Kokoomuksen kansalaisuuspuheessa korostuu kuva aktiivisesta, yritteliäästä kansalaisesta palvelujen muotoilijana ja kehittäjänä. Kansalainen on kokoomuksenkin vaaliohjelmissa palveluiden kohde, mutta samaan aikaan toimija, joka pystyy kehittämään palveluita, kunhan julkinen valta luo kehittämiselle alustan.

12. Tulevaisuuden julkiset palvelut rakennetaan yhdessä kansalaisten kanssa. [...] Avataan palvelujen kehittäminen kansalaisille luomalla hallinnonrajat ylittävä alusta palvelumuotoilulle. (Kokoomus 2015) 
Esimerkissä 12 kansalaisella on aktiivinen toimijarooli suhteessa julkisten palveluiden kehittämiseen. Tämä puhetapa on vain kokoomuksen vaaliohjelmille tyypillinen. Kokoomuksen kansalaisuusdiskurssin voi tulkita olevan yhteneväinen kokoomuksen ideologisen kannattajaprofiilin kanssa: puoluetta äänestävät erityisesti markkinataloutta kannattavat ylemmät toimihenkilöt ja johtajat sekä yrittäjät (Westinen 2016). Kokoomuksen kuvaamassa todellisuudessa kansalaisilla on osaamista, voimavaroja ja mahdollisuuksia kehittää ja muotoilla palveluitaan. Suomessa kansalaisten kuulemiseen ja osallistamiseen on panostettu muun muassa ympäristövaikutuksen arvioinnissa (Laki ympäristövaikutusten arviointimenettelystä 252/2017), terveyspolitiikassa (Jones ja Pietilä 2018) ja osallistavan budjetoinnin muodossa (Meriluoto ja Litmanen 2019). Toisaalta on myös näkemyksiä, joiden mukaan Suomessa ei ole panostettu kansalaisten kuulemiseen tai osallistettu kansalaisia palveluiden kehittämiseen (Leemann ja Hämäläinen 2017).

Kansalaisuuteen liittyvien poliittisten ja sosiaalisten oikeuksien sekä velvollisuuksien tarkastelu eduskuntavaaliohjelmissa osoittaa, että kaikki puolueet puhuvat kansalaisuudesta toisaalta palveluiden kohteena olemisena ja toisaalta omatoimisen kansalaisuuden kautta. Sekä perussuomalaisten, SDP:n, keskustan että kokoomuksen ohjelmissa toistuvana logiikkana on se, että niissä esitetään jokin tärkeänä pidetty kansalaisten kehittymisen tai kehittämisen tarve (kuten omatoimisuus tai aktiivisuus), jota ei sen enempää perustella. Kun tämä tarve on esitetty, jokainen puolue tarjoaa erilaisia ratkaisuja siihen, kuinka asiaa pitäisi edistää. Perussuomalaisten ja SDP:n kansalaisuustulkinnoissa on keskenään samoja elementtejä - ne painottavat valtion ja julkisen vallan keskeistä roolia ihmisten hyvinvoinnin edistäjänä. SDP:stä poiketen perussuomalaisilla painottuu valtion oikeus ohjata ja käyttää valtaa kansalaisiin nähden (paternalismi) sekä EU-kriittisyys. Keskustan ohjelmissa itse toimiva kansalainen korostuu perussuomalaisten tai SDP:n ohjelmia enemmän, mutta keskustankaan ohjelmissa kansalaisten omatoimisuus ja kehittyminen eivät toteudu ilman (hyvinvointi)valtion rakenteita. Kokoomuksen vaaliohjelmissa kansalaisten omatoimisuus ja kehittyvyys ulottuu palveluihin asti: kansalaiset nähdään palvelumuotoilijoina, joilla on kapasiteettia olla jopa palveluiden mahdollistajia (kokoomus 2019).

Puolueet eivät määrittele tai ota kantaa siihen, ovatko kaikki kansalaiset kykeneviä (tuettuun) aktiivisuuteen tai muotoilemaan ja mahdollistamaan palveluita. Helne ym. (2004, 17-18) näkevät riskejä ihmisten itsensä vastuuttamisesta: se saattaa johtaa siihen, että suomalaiset lakkaavat luottamasta instituutioihin. Voi käydä niin, että kansalaisista tulee subjekteja, jotka ovat oikeasti kykeneviä kyseenalaistamaan instituutioiden itsevarmuuksia. Kokoomuskaan ei ota kantaa siihen, miltä hyvinvointivaltion rakenteet näyttäisivät, mikäli kansalaiset lähtisivät radikaalin politiikan mukaisesti niitä muotoilemaan.

On huomionarvoista, että vuodesta 1991 vuoteen 2019 eduskuntavaaliohjelmien kansalaisuuspuhetavoissa ei tapahdu juurikaan muutoksia. Hyvinvointivaltiokansalaisuuteen liittyen ainoastaan digitaalisuus nousee uutena aihiona ohjelmissa esille, SDP:llä ja keskustalla vuoden 2007 ohjelmassa, kokoomuksella vuonna 2015, mutta perussuomalaisilla ei lainkaan. Vaaliohjelmien kansalaisuuspuhe toisin sanoen reagoi hitaasti yhteiskunnassa esillä oleviin teemoihin. Sen sijaan vallalla on vaalivuodesta toiseen julkisen palvelujärjestelmän diskurssi (ks. muu eduskuntavaaliohjelmatutkimus: Karjalainen ym. 2017; Karjalainen ym. 2021/tulossa). Näin siitäkin huolimatta, että käytännössä julkiset palvelut eivät ole enää universaaleja ja käsitykset ja käytännöt hyvinvointivaltion palveluista ovat uudelleen määriteltävinä (Häikiö 2010). 


\section{Kansanvallan diskurssi}

Eduskuntavaaliohjelmissa puhutaan myös vallasta kansalaisuuden yhteydessä. Vaaliohjelmissa kansalaiset nähdään perustuslain $2 \S$ mukaisesti vallankäyttäjinä. Tässä luvussa keskitymme siihen, miten kansalaisen ja valtion välinen oikeudellinen side ja legitimiteetti vaaliohjelmissa tuotetaan. Etenemme analyysissa puolueittain samassa järjestyksessä kuin edellisessä luvussa (perussuomalaiset, SDP, keskusta ja kokoomus).

Perussuomalaisten ohjelmissa on suhteellisesti eniten tekstikatkelmia kansanvallan diskurssiin liittyen verrattuna muihin tarkasteltavina oleviin puolueisiin. Tämä korostaa puolueen populistisia piirteitä: edustuksellista valtaa vastustetaan ja "tavallinen kansa" on jotain, joka "tietää" (ks. Norris ja Inglehart 2019). Puolueen kansalaisdiskurssille on vahvasti leimallista se, että kansalaisuus kuvataan kahtiajakautuneena: "tavallisten" kansalaisten ja "eliittikansalaisten" välillä nähdään olevan perustavanlaatuinen ristiriita. Eliittikansalaisten ja "valtakoneiston" kuvataan käyttävän valtaa epäoikeudenmukaisesti ja epädemokraattisesti tavallista kansaa kohtaan (esimerkki 13).

13. Suomalaisessa yhteiskunnassa kiusaaminen ei rajoitu pelkästään kouluun ja työpaikalle. Monesti kiusaajia ovat myös viranomaiset, jotka kohtelevat kansalaisia epäoikeudenmukaisesti esimerkiksi pompottelemalla heitä luukulta toiselle. (PS 2015)

Kielteinen puhe tarkemmin määrittelemättömästä valtakoneistosta voidaan tulkita populismille ominaiseksi edustuksellisen politiikan ja käytäntöjen vastustamiseksi (ks. Müller 2017; Taggart 2000). Perussuomalaisten kansanvallan diskurssi on joltain osin ristiriidassa edellä esitettyjen kansalaisuusdiskurssien kanssa: perussuomalaisten eduskuntavaaliohjelmissa kansa on samaan aikaan kaikkitietävä, mutta kansalaisia ei saa kuitenkaan päästää toimimaan liian itsenäisesti, vailla "yhteiskunnan" ohjausta ja rakenteita (vrt. esimerkki 2).

SDP:n vaaliohjelmissa kansalaisten luottamus päätöksentekoon ja (poliittiseen) järjestelmään on kansanvallan diskurssin perusta.

14. Uuden vastuun ja luottamuksen syntyminen kansalaisten ja päätöksenteon välille on välttämätöntä - ja se on mahdollista. (SDP 1995)

SDP:n kansanvallan diskurssissa korostuu se, että päätöksenteolla tulee olla kansalaisten luottamus (esimerkki 14). Vaikka puolue korostaa kaikille yhteisten palvelujen merkitystä kansalaisten hyvinvoinnille, SDP:n ohjelmissa valtion ja kansalaisten välinen luottamussuhde kuvataan osin horjuvana, jota siksi on "vahvistettava".

Keskustapuolueen eduskuntavaaliohjelmat noudattelevat kaikille puolueille melko yhtenäistä kansanvallan diskurssia.

15. Keskustan puoluekokous pitää suurten yhteiskunnallisten uudistusten tekemistä mahdollisena vain kansalta saatu tuki ja luottamus selkänojana. (Keskusta 1999)

Keskustan vaaliohjelmissa kansalaiset rakentuvat ylintä valtaa käyttäviksi, joilta saadaan lupa yhteiskunnallisiin uudistuksiin (esimerkki 15). SDP ja keskusta näyttävät siis tekevän hyvin 
samankaltaisia tulkintoja kansanvallasta. Kuitenkin keskustan vaaliohjelmille on tyypillistä, että kansanvalta ja kansanvaltainen yhteiskuntajärjestelmä näyttäytyvät taloudellisesti kilpailukykyisimpänä poliittisena järjestelmänä. Kansanvalta ei siten asetu arvoksi sinänsä vaan talouden menestystekijäksi:

16. Keskusta luottaa siihen, että kansalaisten osallistuminen ja kansanvalta ovat pysyvä voimavara ja kilpailuetu verrattuna harvainvaltaiseen ja kansalaisten oikeuksia polkevaan vallankäyttöön. Kansanvalta on paras myös taloudellisesti, koska se on joustavin ja siksi kestävin. (Keskusta 2011)

Kokoomuksen eduskuntavaaliohjelmissa korostuu kansanedustamisen palveluluonne. Kokoomuksen kansanvallan diskurssi nostaa myös kansanedustajien tai -palvelijoiden moraalin ja eettisyyden diskurssin keskiöön (esimerkki 17). On huomionarvoista, että tämä diskurssi erottaa kokoomuksen muista puolueista.

17. Valtiovalta Suomessa kuuluu kansalle, jota edustaa valtiopäiville kokoontunut eduskunta. Kansalaisilla on oikeus vaatia, että kansanedustajat palvelevat heitä hyvin ja toimivat moraalisesti ja eettisesti hyväksyttävästi. (Kokoomus 1999)

18. Toimiva oikeusvaltio ja järjestystä ylläpitävät viranomaiset ovat turvallisen yhteiskunnan selkäranka. [...]Tästä riippuu viime kädessä kansalaisten luottamus koko demokraattiseen järjestelmään. (Kokoomus 2019)

Esimerkissä 18 kokoomus asettaa vaatimuksia oikeusvaltion ja viranomaisten toiminnalle, jotta ne olisivat kansalaisten luottamuksen arvoisia.

Tässä luvussa tarkastelimme yksilön ja valtion välistä oikeudellista suhdetta ja sen rakentumista puolueiden eduskuntavaaliohjelmissa. Kaikkien neljän puolueen kansanvallan diskurssissa korostuu asetelma, jossa (perustuslain mukaisesti) kansa asetetaan tahoksi, jolta valtuutus ja luottamus poliittisiin päätöksiin on saavutettava. Tämä diskurssi voidaan liittää aiemmassa tutkimuksessa tunnistettuun kansanvaltaisuutta korostavaan puhetapaan (Alasuutari 2006, 49, 57-58, 63). Myös Boltanski ja Thévenot (2006) korostavat kansan tahtoa yhteisöjen toiminnan merkittävänä periaatteena. Kansanvallan diskurssissa ei tapahdu juurikaan muutoksia tarkasteluajanjaksolla.

Taulukkoon 2 (Kansalaisuuden diskurssit eduskuntavaaliohjelmissa) olemme koonneet yhteenvedon keskeisistä tuloksista: kansalaisen poliittiset ja sosiaaliset oikeudet ja velvollisuudet sekä kansalaisen ja valtion välinen oikeudellinen side ja legitimiteetti eduskuntavaaliohjelmissa. 
Taulukko 2. Kansalaisuuden diskurssit eduskuntavaaliohjelmissa (esitysjärjestyksessä).

\begin{tabular}{|c|c|c|c|c|}
\hline \multirow[t]{2}{*}{ PUOLUE } & \multicolumn{2}{|c|}{$\begin{array}{l}\text { Kansalaisten poliittiset ja sosiaaliset oikeudet ja } \\
\text { velvollisuudet }\end{array}$} & \multicolumn{2}{|c|}{$\begin{array}{l}\text { Kansalaisen ja valtion välinen oikeudellinen side ja } \\
\text { legitimiteetti }\end{array}$} \\
\hline & DISKURSSI: & DISKURSSIN KUVAUS: & DISKURSSI: & DISKURSSIN KUVAUS: \\
\hline \multirow[t]{2}{*}{ Perussuomalaiset r.p. } & Palveluiden kohde & $\begin{array}{l}\text { - valtion ja kansalaisen tiivis, } \\
\text { erottamaton suhde } \\
\text { - pohjoismainen } \\
\text { hyvinvointivaltiomalli } \\
\text { kansalaisen turvana ja } \\
\text { pelastajana } \\
\text { - kansalainen uhrina }\end{array}$ & \multirow[t]{2}{*}{ Kansanvalta } & \multirow[t]{2}{*}{$\begin{array}{l}\text { - "tavallisen" kansan } \\
\text { ja "eliittikansan" } \\
\text { vastakkaisasettelu } \\
\text { - kansalainen valtakoneiston } \\
\text { kiusaamana ja uhrina } \\
\text { - "tavallinen" kansa tietää } \\
\text { parhaiten }\end{array}$} \\
\hline & Omatoiminen kansalainen & $\begin{array}{l}\text { - kansalaisen ei sovi olla liian } \\
\text { omatoiminen }\end{array}$ & & \\
\hline \multirow[t]{2}{*}{$\begin{array}{l}\text { Suomen } \\
\text { Sosiaalidemokraattinen } \\
\text { Puolue r.p. }\end{array}$} & Palveluiden kohde & $\begin{array}{l}\text { - valtio kansalaisen turvana } \\
\text { - SDP:n kansalaisuus- } \\
\text { tulkinnassa julkinen valta } \\
\text { tukee, kannustaa, edistää, } \\
\text { luo toimintaedellytyksiä tai } \\
\text { huolehtii }\end{array}$ & \multirow[t]{2}{*}{ Kansanvalta } & \multirow[t]{2}{*}{$\begin{array}{l}\text { - Kansalaisten luottamus } \\
\text { päätöksentekoon ja } \\
\text { (poliittiseen) järjestelmään } \\
\text { on kansalaisuusdiskurssin } \\
\text { perusta }\end{array}$} \\
\hline & Omatoiminen kansalainen & $\begin{array}{l}\text { - omatoimisuutta pitää } \\
\text { julkisen vallan tukea } \\
\text { - omatoimisuus tapahtuu } \\
\text { kansalais(järjestö)toiminnan } \\
\text { puitteissa }\end{array}$ & & \\
\hline \multirow[t]{2}{*}{ Suomen Keskusta r.p. } & Palveluiden kohde & $\begin{array}{l}\text { - omatoimisuus korostuu } \\
\text { enemmän kuin } \\
\text { perussuomalaisilla tai SDP:Illä } \\
\text { - omatoimisuutta ei ole } \\
\text { kuitenkaan olemassa ilman } \\
\text { hyvinvointivaltion rakenteita }\end{array}$ & \multirow[t]{2}{*}{ Kansanvalta } & \multirow[t]{2}{*}{$\begin{array}{l}\text { - kansalaiset ylintä valtaa } \\
\text { käyttävinä, joilta saadaan } \\
\text { lupa yhteiskunnallisiin } \\
\text { uudistuksiin } \\
\text { - kansanvalta ja } \\
\text { kansanvaltainen yhteiskunta- } \\
\text { järjestelmä taloudellisesti } \\
\text { kilpailukykyisimpänä } \\
\text { poliittisena järjestelmänä }\end{array}$} \\
\hline & Omatoiminen kansalainen & $\begin{array}{l}\text { - omatoimisuutta tuetaan } \\
\text { - omatoimisuus kytkeytyy } \\
\text { hyvinvointivaltion } \\
\text { rakenteisiin }\end{array}$ & & \\
\hline \multirow[t]{2}{*}{ Kansallinen Kokoomus r.p. } & Palveluiden kohde & $\begin{array}{l}\text { - kansalainen on palveluiden } \\
\text { kohde, mutta samaan } \\
\text { aikaan toimija, joka pystyy } \\
\text { kehittämään palveluita, } \\
\text { kunhan julkinen valta luo } \\
\text { kehittämiselle alustan. }\end{array}$ & \multirow[t]{2}{*}{ Kansanvalta } & \multirow[t]{2}{*}{$\begin{array}{l}\text { - kansalaisten luottamus } \\
\text { poliittiseen järjestelmään } \\
\text { - kansanedustajien tai } \\
\text {-palvelijoiden moraali ja } \\
\text { eettisyys }\end{array}$} \\
\hline & Omatoiminen kansalainen & $\begin{array}{l}\text { - palveluiden muotoilija ja } \\
\text { mahdollistaja }\end{array}$ & & \\
\hline
\end{tabular}




\section{LOPUKSI}

Tässä artikkelissa tarkastelimme 1) minkälaisia ideologisia eroja neljän suurimman puolueen eduskuntavaaliohjelmissa tuotetaan vuosina 1991-2019 suhteessa kansalaisten poliittisiin ja sosiaalisiin oikeuksiin ja velvollisuuksiin sekä 2) miten kansalaisen ja valtion välinen oikeudellinen side ja legitimiteetti vaaliohjelmissa tuotetaan. Tarkastelimme tutkimuskysymyksiä pohjoismaisesta hyvinvointivaltiomallista käytävän kamppailun viitekehyksestä. Tutkimuksen teoreettiseksi viitekehykseksi valitsimme sosiaalisen konstruktionismin ja tutkimukselliseksi lähestymistavaksi kriittisen diskurssianalyysin. Päädyimme rajaamaan aineistoksi neljän suurimman puolueen vaaliohjelmat, sillä nämä puolueet edustavat 2010-luvulla eduskuntavaaleissa eniten kannatusta saaneita tahoja.

Analyysimme mukaan kansalaisten poliittisiin ja sosiaalisiin oikeuksiin sekä velvollisuuksiin liittyen eduskuntavaaliohjelmista oli tunnistettavissa palveluiden kohteena olevan kansalaisen diskurssi ja omatoimisen kansalaisen diskurssi. Lisäksi eduskuntavaaliohjelmista oli löydettävissä kansanvallan diskurssi. Puolueiden diskurssien väliltä ei löytynyt perustavanlaatuisia näkemyseroja, vaan erot liittyivät enemmänkin painotuksiin. Puolueiden vaaliohjelmissa ei tapahdu juurikaan muutoksia suhteessa kansalaisuuspuheeseen tarkasteluajanjaksolla, edes perussuomalaisten nousu neljän suurimman puolueen joukkoon ei ole tuonut merkittäviä muutoksia muiden puolueiden eduskuntavaaliohjelmien kansalaisuusdiskursseihin.

Sekä perussuomalaiset, SDP, keskusta että kokoomus kannattavat kansalaisten oikeutta palveluihin ja korostavat julkisen vallan roolia kansalaisten hyvinvoinnin takaajana, minkä voidaan tulkita tuottavan turvallisuutta äänestäjille. Toisaalta kaikki puolueet korostavat myös kansalaisten omatoimisuuden ja aktiivisuuden lisäämistä. Tarvetta tähän ei kuitenkaan yleensä erikseen perustella tai esimerkiksi kerrota, miten tarve on kansalaisista havaittavissa. Tämä selittynee sillä, etteivät puolueet halua näyttäytyä holhoavina vallankäyttäjinä, ja tuovat siksi innokkaasti esiin uskoaan kansalaisten oman aktiivisuuden merkitykseen.

Kansanvallan diskurssi on löydettävissä kaikkien tarkasteltavana olleiden puolueiden vaaliohjelmista, mutta se korostuu erityisesti perussuomalaisten ohjelmissa. Perussuomalaisten eduskuntavaaliohjelmissa esiintyvien kansalaisuusdiskurssien suhde on kuitenkin jännitteinen; yhtäältä kansanvaltaa painotetaan ja toisaalta kansalaisten ei odoteta toimivan itsenäisesti, vaan tiiviisti yhteiskunnan hallinnassa. Joka tapauksessa perussuomalaiset erottuu muista kolmesta puolueesta kansanvallan diskurssillaan: perussuomalaisten eduskuntavaaliohjelmapuhe haastaa edustuksellista demokratiaa ja nimeää edustuksellista valtaa käyttäviä tahoja "kiusaajiksi" ja kansalaisia näiden tahojen "uhreiksi". Tällaista edustuksellisen demokratian rakenteiden haastamista ei esiinny SDP:n, keskustan tai kokoomuksen vaaliohjelmissa.

Rose (1996) on todennut, että hyvinvointivaltiokansalaisuus määrittyi solidaarisuuden, turvallisuuden tunteen ja hyvinvoinnin kautta. Eduskuntavaaliohjelmissa painottuva palveluiden kohteena olemisen kansalaisuusdiskurssi vertautuu hyvinvointivaltiokansalaisuuteen. Palveluiden voidaan ajatella tuovan kansalaisille turvaa. Hyvinvointivaltiokansalaisuus on Rosen (1996) mukaan muuttumassa uusliberalistisen kansalaisuuden suuntaan, mikä tarkoittaa vastuullisesti toimivaa, rationaalisia valintoja tekevää ja yrittäjämäistä kansalaista. Eduskuntavaaliohjelmissa puolueet kuitenkin puhuvat kansalaisuudesta lähes pelkästään hyvinvointivaltiokansalaisuuden kautta. Vaaliohjelmissa kyllä esiintyy myös omatoimisen kansalaisen diskurssi, 
mutta se ei tulkintamme mukaan ole sama kuin uusliberalistinen kansalaisuus. Puolueiden vaaliohjelmapuheessa omatoiminen kansalainen voi olla toimija ainoastaan valtion rakenteiden mahdollistamana. Näyttää siltä, että puolueet eivät tee politiikkaa eduskuntavaaliohjelmissaan uusliberalistisella, aktiivisella kansalaisuudella vaan puhumalla palvelujärjestelmästä. Myös aikaisemmissa tutkimuksissa on havaittu, että esimerkiksi lapset ja vanhukset eivät tule esille aktiivisina toimijoina eduskuntavaaliohjelmissa. Sen sijaan heidän toimijuutensa rakentuu palvelujärjestelmän kautta. (Karjalainen ym. 2021/tulossa.)

Kriittiselle diskurssianalyysille on ominaista kielenkäytön seurauksien tarkastelu (esim. Mullet 2018). Johdannossa totesimme puolueiden kansalaisuuskäsityksillä olevan merkitystä harjoitettavalle politiikalle, päätöksenteolle ja esimerkiksi kansalaisiin kohdistuvan palvelujärjestelmän muotoutumiselle. Suoraviivainen johtopäätös olisi näin ollen, että koska kaikilla neljällä suurimmalla puolueella eduskuntavaaliohjelmissa painottuu kattava, melko universaali palvelujärjestelmä, olisi toteutettava politiikka myös palvelujärjestelmää vahvistava. Kuitenkin, kuten Wallgren (2008) toteaa, puolueet toimivat usein vastoin julkilausuttuja tarkoituksiaan. Osittain näin voidaan tulkita käyvän myös eduskuntavaaliohjelmien kohdalla.

Puolueet vakuuttavat, että hyvinvointipalvelut kattavat kansalaisten tarpeet. Todellisuudessa palvelujen universaalius on murtumassa ja hyvinvointivaltion toimintamalleja määritellään uudestaan (Häikiö 2010). Peruspalvelutarjontaa ollaan alistamassa vapaakaupan säännöille (Wallgren 2008) ja lisäksi palveluista huolehtivat myös kolmas sektori, yritykset, lähiyhteisöt ja omaiset (Häikiö ym. 2011). Suomalainen sosiaalipolitiikka on muuttunut yksilön aktiivista vastuunottoa korostavaksi (Julkunen 2001; Kananen 2008; Siisiäinen ym. 2014, 89). Kun vaaliohjelmissa kansalaisuuden ympärille rakentuva hyvinvointivaltiokansalaisuuslupaus ei täyty, se ei ole omiaan lisäämään luottamusta ja kiinnostusta politiikkaan. Alho (2008) toteaakin, että "politiikan ongelmat näkyvät erityisesti vaaliohjelmissa". Puolueet eivät suoranaisesti ota kantaa universalismin murtumiseen. Kuitenkin erityisesti keskustan ja kokoomuksen vaaliohjelmat sisältävät viittauksia kansalaisten omaan aktiivisuuteen ja esimerkiksi kykyyn huolehtia lähimmäistensä hyvinvoinnista. Nämä lausumat yhdessä kokoomuksen palvelumuotoilupuheen kanssa linkittyvät muutokseen julkisten palveluiden universalismiperiaatteessa. Näin tulkiten näyttää siltä, että perussuomalaiset ja SDP kannattavat vaaliohjelmissaan vankemmin pohjoismaista, "perinteistä", hyvinvointivaltiomallia universaaleine palveluineen. Keskusta ja kokoomus sen sijaan nostavat esiin mahdollisuuden siitä, että palvelut voisivat olla myös muuten kuin valtiovetoisesti järjestettyjä.

Artikkelissa toimme myös esille puolueiden ideologioita ja niin sanottujen vanhojen puolueiden muutosta intressipuolueista yleispuolueiksi. Vanhojen puolueiden yleispuolueistuminen sekä jäsenmäärän ja kannatuksen lasku yhdistettynä niin sanottujen uusien puolueiden esiin nostamiin uusiin politiikkateemoihin sekä niiden jäsenmäärän ja kannatuksen nousu (Isotalo ym. 2019; Koivula 2019, 41) muodostivat tämä tutkimuksen kannalta kiintoisan ja jännitteisen poliittisen viitekehyksen. Yleispuolueistuminen on vähentänyt SDP:n, keskustan ja kokoomuksen jäsenmääriä ja kannatusta (ks. taulukko 1). Sen sijaan perussuomalaiset on viime vuosina lisännyt jäsenmääräänsä ja kannatustaan. Perussuomalaisten vaaliohjelmissa painottuu kansanvallan diskurssi - "tavallinen kansa" korotetaan vallankäyttäjän asemaan ohi viranomaisten tai "valtakoneiston". Vaikka perussuomalaisten eduskuntavaaliohjelmien kansalaisuusdiskurssi on monella tapaa sisäisesti ristiriitainen, herää kysymys, onko siitä huolimatta heidän käyttämänsä 
kansalaisuusdiskurssi yhdistettynä puolueen suoran demokratian rakenteeseen ${ }^{2}$ edistäneet puolueen kannatuksen huomattavaa kasvua?

Tutkimusaineistomme koostui vain neljän suurimman puolueen vaaliohjelmista. Niin sanotuista uusista puolueista myös vasemmistoliitto ja vihreät ovat olleet tarkasteluajanjaksolla hallitusvastuussa, mutta näiden puolueiden eduskuntavaaliohjelmia ei tarkasteltu tässä tutkimuksessa. Jatkossa olisi tarpeellista tutkia mitä muutoksia puolueiden diskursseissa tapahtuu, kun vaalikamppailu vaihtuu hallitusvastuuseen. Lisäksi olisi tarpeen tarkastella eduskuntavaaliohjelmien suhdetta toteutettavaan politiikkaan: missä määrin ja millä "logiikalla" eduskuntavaaliohjelmissa tehdyt lupaukset täyttyvät toteutettavassa politiikassa. Myös eduskuntavaaliohjelmissa tuotetut osallisuuden (inkluusio) ja syrjäytymisen (ekskluusio) diskurssit ovat keskeisiä tutkimuskohteita: esimerkiksi maahanmuuttajiin liitetyt diskurssit ja niiden tutkiminen hyvinvointisovinismin viitekehyksessä toisi näkyväksi puolueiden mahdolliset erot tai yhtäläiset maahanmuuttajiin liittyvissä ideologioissa.

\section{VIITTEET}

1. Varsinkin hyvinvointiyhteiskunta käsitteenä on luonteeltaan ei-koskaan-valmis (Eräsaari 2000, 37) ja sen takia määrittelemätön, "epämääräinen". Voidaan jopa sanoa, että hyvinvointiyhteiskunta on poliittisena käsitteenä tyhjä (ks. Alho 2008).

2. Kuten jäsenistön mahdollisuus osallistua puoluejohdon ja puolueen puheenjohtajan valintaan (Koiranen ym. 2019, 311).

\section{LÄHTEET}

Ahponen, Pirkkoliisa. 2001. Kulttuurin pesäpaikka. Yhteiskunnallisia lähestymistapoja kulttuuriteoriaan. Helsinki: WSOY.

Alanen, Leena. 2009. Johdatus lapsuudentutkimukseen. Teoksessa Leena Alanen ja Kirsti Karila (toim.), Lapsuus, lapsuuden instituutiot ja lasten toiminta. Tampere: Vastapaino, 9-30.

Alasuutari, Pertti. 2006. Suunnittelutaloudesta kilpailutalouteen: miten muutos oli ideologisesti mahdollinen? Teoksessa Risto Heiskala ja Eeva Luhtakallio (toim.), Uusi jako. Miten Suomesta tuli kilpailukyky-yhteiskunta? Helsinki: Gaudeamus, 43-64.

Alho, Arja. 2008. Kun kaikki pyhä haihtuu. Teoksessa Hanna Kuusela ja Mika Rönkkö (toim.), Puolueiden kriisi. Puolueet ja uusliberalismi: Mitä on tehtävä. Helsinki: Like Kustannus, 35-43.

Berg, Päivi ja Salasuo, Mikko. 2016. Liikkuva luokka. Liikunnan harrastaminen kunnon kansalaisuutena. Yhteiskuntapolitiikka 82:3, 251-261.

Boltanski, Luc ja Thévenot, Laurent. 2006. On Justification: Economies of Worth. Princeton: Princeton University Press.

Eräsaari, Risto. 2000. Sosiaalipolitiikan viitekehys: aika, yhteiskunta, yhteisö, maailma. Teoksessa Eija Nurminen (toim.), Sosiaalipolitiikan lukemisto. Helsinki: Palmenia, 35-64. 
Esping-Andersen, Gosta. 1990. The Three Worlds of Welfare Capitalism. Cambridge: Polity press.

Fairclough, Norman. 2003. Analysing Discourse: Textual Analysis for Social Research. London, New York: Routledge.

Fairclough, Norman. 2010. Critical Discourse Analysis. The Critical Study of Language. New York: Routledge.

Freeden, Michael. 2019 [2003]. Mitä on ideologia? Tampere: Eurooppalaisen filosofian seura ry.

Gergen, Kenneth J. 1985. The Social Constructionist Movement in Modern Psychology. American Psychologist 40:3, 266-275. https://doi.org/10.1037/0003-066X.40.3.266

Hacking, Ian. 2009. Mitä sosiaalinen konstruktionismi on? Tampere: Vastapaino.

Harjula, Minna. 2015. Hoitoonpääsyn hierarkiat. Terveyskansalaisuus ja terveyspalvelut Suomessa 1900-luvulla. Tampere: Tampereen Yliopistopaino Oy - Juvenes Print.

Helne, Tuula. 2004. Syrjäytymisen solmut - eli miksi syrjäytymisestä puhuminen on niin hankalaa. Teoksessa Tuula Helne, Sakari Hänninen ja Jouko Karjalainen (toim.), Seis yhteiskunta- tahdon sisään! Jyväskylä: Minerva Kustannus Oy, 23-53.

Hvinden, Bjorn ja Johansson, Håkan. 2007. Citizenship in Nordic Welfare States: Dynamics of choice, duties and participation in a changing Europe. Lontoo: Routledge.

Hyssälä, Liisa ja Backmann, Jouni. 2018. Kansanvallan peruskorjaus. Kaikki voimavarat käyttöön. Sitra työpaperi 23.2.2018. Helsinki: Sitra.

Hyvärinen, Matti. 2003. Valta. Teoksessa Matti Hyvärinen, Jussi Kurunmäki, Kari Palonen, Tuija Pulkkinen, ja Henrik Stenius (toim.), Käsitteet liikkeessä. Tampere: Vastapaino, 63-116.

Häikiö, Liisa. 2010. The Diversity of Citizenship and Democracy in Local Public Management Reform. Public Management Review 12:3, 363-384. htps://doi.org/10.1080/14719030903286649

Häikiö, Liisa, van Aerschot, Lina ja Anttonen, Anneli. 2011. Vastuullinen ja valitseva kansalainen: vanhushoivapolitiikan uusi suunta. Yhteiskuntapolitiikka 76:3, 239-250.

Isotalo, Veikko, Järvi, Theodora, von Schoultz, Åsa ja Söderlund, Peter. 2019. Suomalainen äänestäjä 2003-2019. Oikeusministeriö.

Johansson, Jan. 2010. Kansalaisuus ja yhteiskunnallinen yhteisö. T.H. Marshallin ja Talcott Parsonin perintö nykyaikaiselle kansalaisuustutkimukselle. Helsinki: Yliopistopaino.

Jokinen, Arja, Juhila, Kirsi ja Suoninen, Eero. 2016. Diskursiivinen maailma. Teoreettiset lähtökohdat ja analyyttiset käsitteet. Teoksessa Arja Jokinen, Kirsi Juhila ja Eero Suominen (toim.), Diskurssianalyysi. Teoriat, peruskäsitteet ja käyttö. Tampere: Vastapaino, 25-50.

Jones, Marjaana ja Pietilä, Ilkka. 2018. The citizen is stepping into a new role - policy interpretations of patient and public involvement in Finland. Health and Social Care in the Community. 2018, 26:2, e304-e311. htps://doi.org/10.1111/hsc. 12520

Julkunen, Raija. 2001. Suunnanmuutos. 1990-luvun sosiaalipoliittinen reformi Suomessa. Jyväskylä: Vastapaino.

Julkunen, Raija. 2017. Muuttuvat hyvinvointivaltiot. Eurooppalaiset hyvinvointivaltiot reformoitavina. Jyväskylä: SoPhi.

Kananen, Johannes. 2008. Kilpailukyky ja tuottavuus 2000-luvun sosiaalipolitiikassa. Yhteiskuntapolitiikka 73:3, 239-249.

Kananen, Marko, Ronkainen, Jussi ja Saari, Kari. 2018. Kansallisuusorientaatiot Nuorten SuomiVenäjä-kaksoiskansalaisten yhteiskunnalliset ja ylirajaiset siteet. Yhteiskuntapolitiikka 83:5-6, 518531. 
Kangasvuo, Jenny. 2014. Suomalainen biseksuaalisuus: käsitteen ja kokemuksen kulttuuriset ehdot. Tampere: Juvenes Print.

Kantola, Anu. 2006. Suomea trimmaamassa: suomalaisen kilpailuvaltion sanastot. Teoksessa Risto Heiskala ja Eeva Luhtakallio (toim.), Uusi jako. Miten Suomesta tuli kilpailukyky-yhteiskunta? Helsinki: Gaudeamus, 156-178.

Karjalainen, Anne-Maria, Luodonpää-Manni, Milla ja Laippala, Veronika. 2017. Hyvinvointivaltio ja kielitietoisuus: Hyvinvoinnin diskurssit neljän suurimman puolueen eduskuntavaaliohjelmissa. Teoksessa Sirkku Latomaa, Emilia Luukka ja Niina Lilja (toim.), Kielitietoisuus eriarvoistuvassa yhteiskunnassa. Suomen soveltavan kielitieteen yhdistyksen julkaisuja n:o 75. Jyväskylä: Suomen soveltavan kielitieteen yhdistys AFinLA.

Karjalainen, Anne-Maria, Ukkonen-Mikkola, Tuulikki, Luodonpää-Manni, Milla ja Pietilä, Ilkka. 2021/ tulossa. Lasten ja vanhusten toimijuus: diskurssianalyysi neljän puolueen eduskuntavaaliohjelmista. Janus.

Karvonen, Lauri. 2014. Parties, Governments and Voters in Finland: Politics Under Fundamental Societal Transformation. ECPR Press.

Katz, Richard S. 2013. Intra-party democracy would arrest party decline? Teoksessa William P. Cross ja Richard S. Katz (toim.), The challenges of intra-party democracy. Oxford: Oxford University Press, 49-64.

Keskusta 1999. Omistamisella on väliä.

Keskusta 2011. Suomen Keskusta. Vaaliohjelma vuoden 2011 eduskuntavaaleihin.

Keskusta 2019. Keskustan vaaliohjelma. Eduskuntavaalit 2019.

Kettunen, Pauli, 2003. Yhteiskunta. Teoksessa Matti Hyvärinen, Jussi Kurunmäki, Kari Palonen, Tuija Pulkkinen ja Henrik Stenius (toim.), Käsitteet liikkeessä. Tampere: Vastapaino, 167-211.

Koiranen, Ilkka, Koivula, Aki, Mickelsson, Rauli ja Saarinen, Arttu. 2019. Kenen joukoissa seisot ja kenen puolesta toimit? SDP:n ja vihreiden puoluekokoukset edustavuuden näkökulmasta. Politiikka 61:4, 308-336.

Koivula, Aki. 2019. The choice is yours but it is politically tinged: The social correlates of political party preferences in Finland. Turku: Turun Yliopisto.

Kokkonen, Tuomo. 2004. Sosiaaliset oikeudet ja sosiaalipolitiikka: T. H. Marshallin näkökulma hyvinvointivaltioon. Politiikka 46:4, 207-225.

Kokoomus 1991. Eduskuntavaalit 1991. Kokoomuksen vaalitavoitteet.

Kokoomus 1995. KANSALLINEN KOKOOMUS. Järvenpää 28.1.1995. Vaalikampanjan avaus - vaalitavoitteita.

Kokoomus 1999. Puoluehallitus 7.4.1998. Vaalilupaus.

Kokoomus 2015. Jos vanha tapa ei toimi, tarvitaan KORJAUSLIIKE.

Kokoomus 2019. Kokoomuksen eduskuntavaaliohjelma 2019: Luotamme Suomeen.

Koskinen, Henri ja Saarinen, Arttu. 2019. Innovaatioita, kasvua ja yrittäjämäisiä kansalaisia: Yrittäjyyspuhe suomalaisissa hallitusohjelmissa 1979-2015. Sosiologia 56:2, 141-156.

Lagerspetz, Eerik. 2018. Vaikutusperiaate ja demokratia. Politiikka 60:4, 277-289.

Lappalainen, Pertti. 2017. Kohti kiistelevää kansalaistoimintaa. Yhteiskuntapolitiikka 82:3, 350-356.

Leemann, Lars ja Hämäläinen, Riitta-Maija. 2016. Asiakasosallisuus, sosiaalinen osallisuus ja matalan kynnyksen palvelut. Pohdintaa käsitteiden sisällöstä. Yhteiskuntapolitiikka 81:5, 586-594.

Lindström, Lisbeth. 2010. Youth Citizenship and the Millennium Generation. Citizenship, Social and Economics Education 9:1, 48-59. https://doi.org/10.2304/csee.2010.9.1.48 
Lister, Ruth. 2003. Citizenship. Feminist Perspective. Second edition. New York: Palgrave Macmillan.

Mannerström, Rasmus, Muotka Joona, Leikas, Sointu ja Lönnqvist, Jan-Erik. 2020. Hyvin toimeentuleva, terve ja suvaitsematon - Suomalaisten nuorten poliittiset ideologiat asenneprofilleina tarkasteltuna. Politiikka 62:1, 9-32. https://doi.org/10.37452/politiikka.83247

Marshall, Thomas Humphrey. 1950. Citizenship and Social Class 1950. Cambridge: University Press.

Matthies, Aila-Leena. 2017. Osallistumisen lupaus ja petos hyvinvointipalveluissa. Sosiologia 54:1, 149-165.

Mattila, Mikko ja Raunio, Tapio. 2006. Cautious voters-supportive parties: Opinion congruence between voters and parties on the EU dimension. European Union Politics 7:4, 427-449. https://doi.org/10.1177/1465116506069434

Meriluoto, Taina ja Litmanen, Tapio. 2019. Osallistu! - Pelastaako osallistaminen demokratian? Tampere: Vastapaino.

Mickelsson, Rauli. 2007. Suomen puolueet. Historia, muutos ja nykypäivä. Tampere: Vastapaino.

Mickelsson, Rauli. 2015. Suomen puolueet - vapauden ajasta maailmantuskaan. Tampere: Vastapaino.

Mullet, Dianna. R. 2018. A General Critical Discourse Analysis Framework for Educational Research. Journal of Advanced Academics 29:2, 116 -142. https://doi.org/10.1177/1932202X18758260

Müller, Jan-Werner. 2017. Mitä on populismi? Tampere: Eurooppalaisen filosofian seura ry.

Möttönen. Sakari. 2009. Ovatko järjestöt hyvinvointivaltion purkajia vai puolustajia? Yhteiskuntapolitiikka 74:1, 60-71.

Nikander, Pirjo ja Zechner, Minna. 2006. Ikäetiikka - elämänkulun ääripäät, haavoittuvuus ja eettiset kysymykset. Yhteiskuntapolitiikka 71:5, 515-526.

Norris, Pippa ja Inglehart, Ronald. 2019. Cultural Backlash: Trump, Brexit, and Authoritarian Populism. Cambridge: Cambridge University Press.

Nykänen, Hanna, Mikkola, Leena ja Asunta, Laura. 2018. Sosiaalipalveluiden työntekijöiden ja vammaisten asiakkaiden vuorovaikutuksen diskurssit asiakkaiden blogikeskusteluissa. Janus 26:3, 208-227. https://doi.org/10.30668/janus.67872

Outinen, Sami. 2017. From Steering Capitalism to Seeking Market Acceptance. Social Democrats and employment in Finland, 1975-1998. Scandinavian Journal of History 42:4, 389-413. https://doi.org/10.1080/03468755.2017.1336599

Paloheimo, Heikki ja Wiberg, Matti. 1997. Politikan perusteet. Porvoo: WSOY.

Paloheimo, Heikki ja Sundberg, Jan. 2005. Puoluevalinnan perusteet. Teoksessa Heikki Paloheimo (toim.), Vaalit ja demokratia Suomessa. Helsinki: WSOY.

Palonen, Emilia. 2020. Populismin muoto, diskursiivisuus ja retoriikka: analyysi soinilaisuudesta. Politiikka 62:2, 125-145. https://doi.org/10.37452/politiikka.89431.

Palonen, Emilia ja Saresma, Tuija. 2017. Jätkät ja jytkyt - Perussuomalaiset ja populismin retoriikka. Tampere: Vastapaino.

Palonen, Kari. 1987. Politiikan ilmiöt vai politiikan ilmiö? Politiikka 29:4, 305-321.

Perussuomalaiset 2003. Perussuomalaisten Eduskuntavaaliohjelma 2003.

Perussuomalaiset 2011. Suomalaiselle sopivin. Perussuomalaiset r.p:n eduskuntavaaliohjelma 2011.

Perussuomalaiset 2015. Perussuomalaisten eduskuntavaaliohjelma.

Pirkkalainen, Päivi, Wass, Hanna ja Weide, Marjukka. 2016. Suomen somalit osallistuvina kansalaisina. Yhteiskuntapolitiikka 81:1, 69-77.

Poutanen, Mikko. 2018. Business Meets Politics. Intertwined economic and political discursive structures in the case of Nokia in Finland. Tampere: Tampere University Press. 
Pynnönen, Anu. 2015. Varjosta valokeilaan. Kriittisiä diskurssianalyysejä huonosta johtamisesta. Jyväskylä: Jyväskylä University Printing House.

Ronkainen, Jussi, Harinen, Päivi, Rautapuro, Juhani ja Pitkänen, Pirkko. 2006. Kahden valtion kansalaiset. Kansanedustajien, viranomaisten ja kansalaisjärjestötoimijoiden näkemyksiä kaksoiskansalaisuudesta. Yhteiskuntapolitiikka 71:1, 59-72.

Ronkainen, Jussi. 2009. Väliviivakansalaiset. Monikansalaisuus asemana ja käytäntönä. Yhteiskuntatieteellisiä julkaisuja 103. Joensuu: University of Joensuu.

Rose, Nikolas. 1996. Governing "Advanced" Liberal Democraties. Teoksessa Andrew Barry, Thomas Osborne ja Nikolas Rose (toim.), Foucault and Political Reason. Liberalism, Neo-liberalism and Rationalities of Government. London: UCL Press, 37-64.

Ruostetsaari, Ilkka ja Borg, Sami. 2004. Sukupolvien valta-asemien muutos eliiteissä ja eduskunnassa. Yhteiskuntapolitiikka 69:2, 147-158.

Saarinen, Arttu, Salmenniemi, Suvi ja Keränen, Harri. 2014. Hyvinvointivaltiosta hyvinvoivaan valtioon. Hyvinvointi ja kansalaisuus suomalaisessa poliittisessa diskurssissa. Yhteiskuntapolitiikka 79:6, 605-618. SDP 1995. Uuden vastuun aika.

SDP 2007. Vaaliohjelma. Reilu Suomi - työtä ja välittämistä.

SDP 2019. Tulevaisuuslinja. Sdp:n vaalitavoitteita. Ja muutoksen suunta 2030.

Selkälä, Arto. 2013. Kansalaisuuden hallinta suomalaisessa sosiaali- ja terveyspolitiikassa. Lapin yliopisto, Yhteiskuntatieteiden tiedekunta. Rovaniemi: Lapin yliopistokustannus.

Siisiäinen, Martti, Kankainen, Tomi ja Luhtakallio, Eeva. 2014. Työttömien liike. Teoksessa Kirsti Lempiäinen ja Tiina Silvasti (toim.), Eriarvoisuuden rakenteet. Haurastuvat työmarkkinat Suomessa. Tallinna: Vastapaino, 52-90.

Siltaoja, Marjo ja Vehkaperä, Meri. 2011. Diskurssianalyysi johtamis- ja organisaatiotutkimuksessa. Teoksessa Anu Puusa ja Pauli Juuti (toim.), Menetelmäviidakon raivaajat. Perusteita laadullisen tutkimuslähestymistavan valintaan. Jyväskylä: Hansaprint, 206-231.

Silvasti, Tiina, Lempiäinen, Kirsti ja Kankainen, Tomi. 2014. Eriarvoisuuden uudet paikat. Teoksessa Kirsti Lempiäinen ja Tiina Silvasti (toim.), Eriarvoisuuden rakenteet. Haurastuvat työmarkkinat Suomessa. Tallinna: Vastapaino, 52-90.

Sipponen, Kauko. 2000. Kansalainen - isäntä vai renki. Vantaa: Tummavuoren kirjapaino Oy.

Soini, Timo. 2020. Populismi. Kunnallisalan kehittämissäätiön Polemia-sarjan julkaisu nro 116.

Solomos, John. 2014. Stuart Hall: articulations of race, class and identity. Ethnic and Racial Studies, 37:10, 1667-1675. https://doi.org/10.1080/01419870.2014.931997

Stenius, Henrik. 2003. Kansalainen. Teoksessa Matti Hyvärinen, Jussi Kurunmäki, Kari Palonen, Tuija Pulkkinen ja Henrik Stenius (toim.), Käsitteet liikkeessä. Tampere: Vastapaino, 309-362.

Taggart, Paul. 2000. Populism. Philadelphia: Open University Press.

Torkki, Juhana. 2014. Tarinan valta. Kertomus luolamiehen paluusta. Keuruu: Otava.

Wallgren, Thomas. 2018. Mahdottoman mahdollisuus. Teoksessa Hanna Kuusela ja Mika Rönkkö (toim.), Puolueiden kriisi. Puolueet ja uusliberalismi: Mitä on tehtävä. Helsinki: Like Kustannus, 19-33.

van Dijk, Teun A. 2010. Critical Discourse Analysis. Teoksessa Deborah Schiffrin, Deborah Tannen ja Heidi E. Hamilton (toim.), The Handbook of Discourse Analysis. New Jersey: Wiley, 466-487.

Westinen, Jussi. 2016. Puoluevalinta Suomessa 2000-luvulla. Teoksessa Kimmo Grönlund ja Hanna Wass (toim.), Polittisen osallistumisen eriytyminen. Eduskuntavaalitutkimus 2015. Selvityksiä ja ohjeita Oikeusministeriön julkaisu 28/2016. Helsinki: Lönnberg Print \& Promo, 249-272. 
Virsu, Ville. 2007. Sosiaalisten ongelmien retoriikkaa: tapaus doping. Virittäjä 111:3, 346-366.

Wodak, Ruth. 2005. New Agenda in (Critical) Discourse Analysis: Theory, Methodology and Interdisciplinarity. Amsterdam: John Benjamins Publishing Company.

Wodak, Ruth ja Fairclough, Norman. 1997. Critical Discourse Analysis. Teoksessa Teun A. van Dijk (toim.), Discourse as Social Interaction. London: Sage, 258-284.

Wodak, Ruth ja Meyer, Michael. 2009. Critical discourse analysis: History, agenda, theory and methodology. Teoksessa Ruth Wodak ja Michael Mayer (toim.), Methods of Discourse Analysis, 2nd Edition. London: Sage, 1-33.

Vuori, Jaana. 2015. Kotoutuminen arjen kansalaisuuden rakentamisena. Yhteiskuntapolitiikka 80:4, 395404.

Ylä-Anttila, Tuomas ja Ylä-Anttila, Tuukka. 2015. Exploiting the Discursive Opportunity of the Euro Crisis: The Rise of the Finns Party. Teoksessa Hanspeter Kriesi ja Takis S. Pappas (toim.), European Populism in the Shadow of the Great Recession. United Kingdom: ECPR Press, 80-103.

\title{
KIRJOITTAJATIEDOT
}

\author{
ANNE-MARIA KARJALAINEN \\ YTM, tohtoriopiskelija \\ Valtiotieteellinen tiedekunta \\ Helsingin yliopisto \\ annemaria.karjalainen@gmail.com \\ ILKKA PIETILÄ \\ FT, apulaisprofessori \\ Valtiotieteellinen tiedekunta \\ Helsingin yliopisto \\ ilkka.pietila@helsinki.fi \\ TUULIKKI UKKONEN-MIKKOLA \\ KT, yliopistonlehtori \\ Kasvatustieteiden ja psykologian tiedekunta \\ Jyväskylän yliopisto \\ tuulikki.t.ukkonen-mikkola@jyu.fi
}

